\title{
Carbon Dioxide Mineralization Feasibility in the United States
}

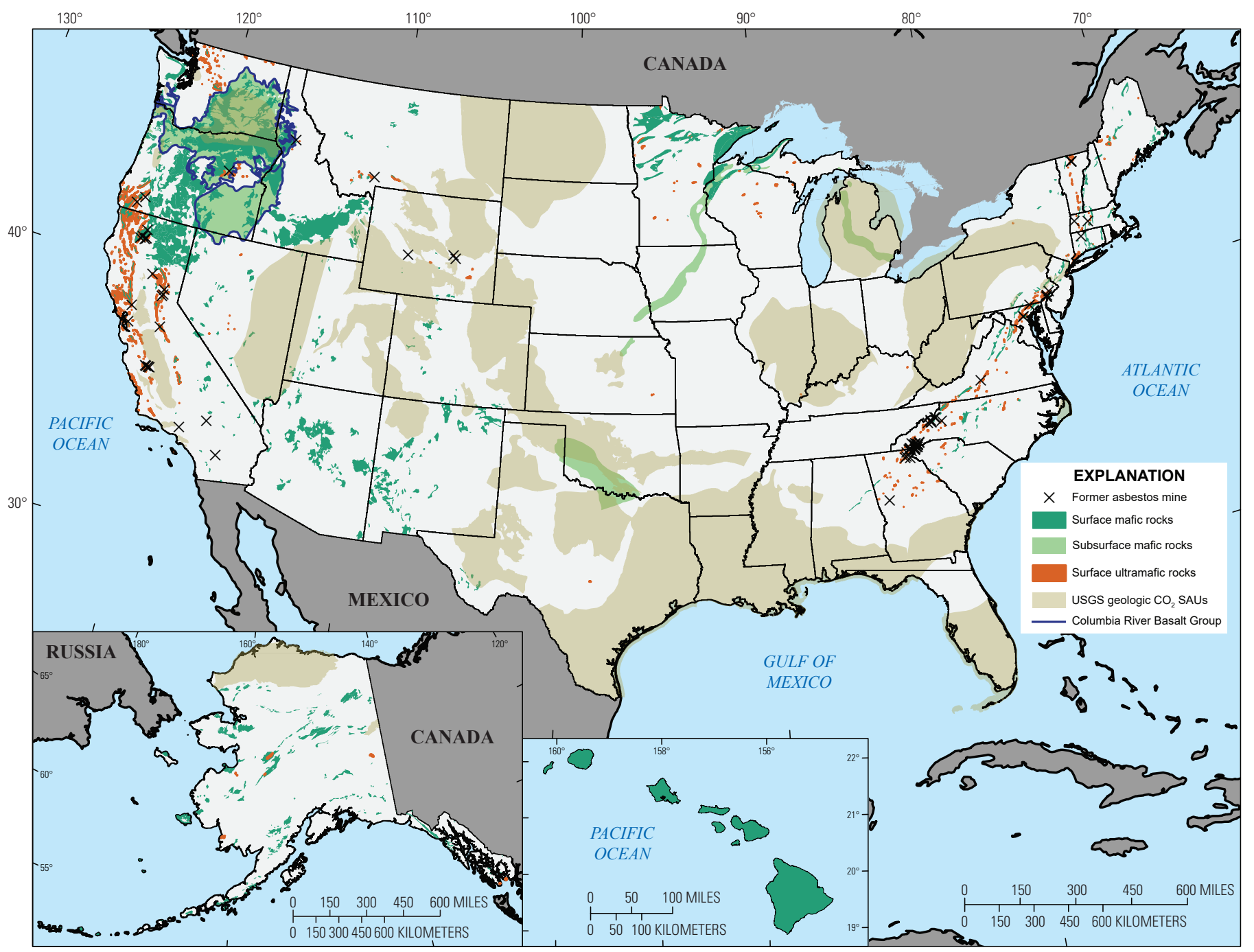

Scientific Investigations Report 2018-5079 
Cover. National map of mafic and ultramafic rocks in the United States. See figure 1. [USGS, U.S. Geological Survey; $\mathrm{CO}_{2}$, carbon dioxide; $\mathrm{SAU}$, storage assessment unit] 


\section{Carbon Dioxide Mineralization Feasibility in the United States}

By Madalyn S. Blondes, Matthew D. Merrill, Steven T. Anderson, and Christina A. DeVera

Scientific Investigations Report 2018-5079 


\section{U.S. Department of the Interior DAVID BERNHARDT, Acting Secretary}

\section{U.S. Geological Survey James F. Reilly II, Director}

U.S. Geological Survey, Reston, Virginia: 2019

For more information on the USGS — the Federal source for science about the Earth, its natural and living resources, natural hazards, and the environment-visit https://www.usgs.gov or call 1-888-ASK-USGS.

For an overview of USGS information products, including maps, imagery, and publications, visit https://store.usgs.gov.

Any use of trade, firm, or product names is for descriptive purposes only and does not imply endorsement by the U.S. Government.

Although this information product, for the most part, is in the public domain, it also may contain copyrighted materials as noted in the text. Permission to reproduce copyrighted items must be secured from the copyright owner.

Suggested citation:

Blondes, M.S., Merrill, M.D., Anderson, S.T., and DeVera, C.A., 2019, Carbon dioxide mineralization feasibility in the United States: U.S. Geological Survey Scientific Investigations Report 2018-5079, 29 p., https://doi.org/10.3133/ sir20185079.

ISSN 2328-0328 (online) 


\section{Preface}

The U.S. Geological Survey (USGS) has decades of experience in devising and testing methods for objectively assessing energy and mineral resources. Geologic storage is one potential method for sequestering atmospheric and anthropogenic $\mathrm{CO}_{2}$. The injection of $\mathrm{CO}_{2}$ in sedimentary reservoirs is the most commonly discussed form of geologic $\mathrm{CO}_{2}$ storage. This report discusses the feasibility of an alternative form of geologic $\mathrm{CO}_{2}$ storage: $\mathrm{CO}_{2}$ mineralization. In this method, storage is achieved by the formation of stable, solid carbonate minerals. This report was prepared in response to a request from the Senate Interior, Environment, and Related Agencies Subcommittee. ${ }^{1}$

The Survey is urged to conduct a study on the feasibility of carbon mineralization for permanent sequestration of carbon dioxide emissions, as described in the recently published report, "Rapid Carbon Mineralization for Permanent Disposal of Anthropogenic Carbon Dioxide Emissions," with specific focus on the technical feasibility and potential sequestration sites. The Survey should consult with EPA, the Department of Energy, and other relevant agencies.

—Senate Committee on Appropriations, 2016, p. 37

\section{Acknowledgments}

We appreciate the helpful external reviews from Peter B. Kelemen of the Lamont-Doherty Earth Observatory, Columbia University Earth Institute, and Greeshma Gadikota of the Department of Civil and Environmental Engineering and the Wisconsin Energy Institute at the University of Wisconsin, Madison. We also thank Bruce J. Kobelski of the U.S. Environmental Protection Agency, Office of Ground Water and Drinking Water, and Jeffrey Summers of the U.S. Department of Energy, Division of Fossil Energy, for their insights and discussions.

We also appreciate the thorough internal reviews and insights from Anne E. McCafferty and Bradley S. Van Gosen of the U.S. Geological Survey (USGS). We further would like to thank Peter D. Warwick, Robert R. Seal II, Jane M. Hammarstrom, Gilpin R. Robinson, Jr., and William F. Cannon, all of the USGS; and we appreciate the help of Adria Peterkin, USGS intern, and Varun Saraswathula, USGS student volunteer, for preliminary work related to this report.

\footnotetext{
${ }^{1}$ Senate Committee on Appropriations, 2016, Department of the Interior, environment, and related agencies appropriations bill, 2017: U.S. Congress, 114th, Senate Report 114-281, to accompany S. 3068, 153 p., accessed July 1, 2017, at https://www.congress.gov/congressional-report/114th-congress/senate-report/281/1.
} 



\section{Contents}

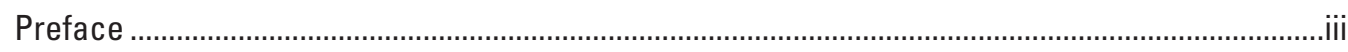

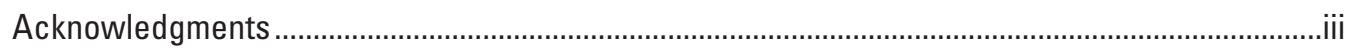

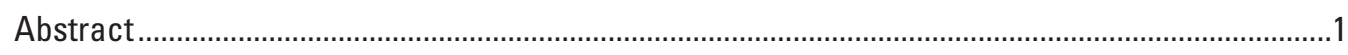



2. Reaction Rate Experiments and Models ..........................................................................

3. In Situ Carbon Dioxide Mineralization.................................................................................

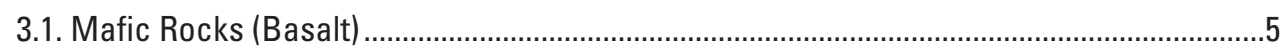

3.2. Ultramafic Rocks (Dunite, Peridotite, and Serpentinite) ..................................................5

4. Ex Situ Carbon Dioxide Mineralization ..................................................................................

4.1. Carbon Dioxide Mineralization of Mine Tailings ................................................................

4.2. Carbon Dioxide Mineralization of Alkaline Industrial Wastes...........................................10

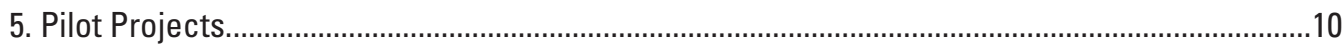

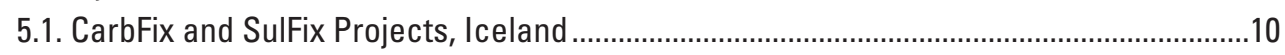

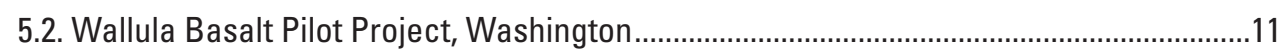

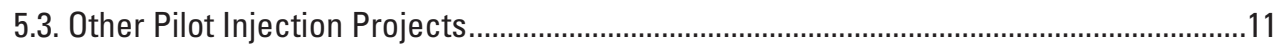

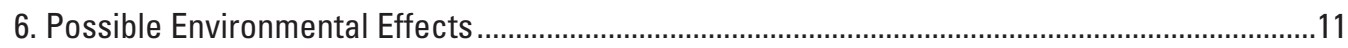

7. Economic Constraints and Risk ..........................................................................................12

8. Regional Carbon Dioxide Mineralization Feasibility in the United States ....................................13

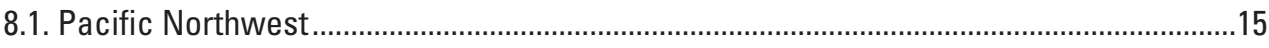

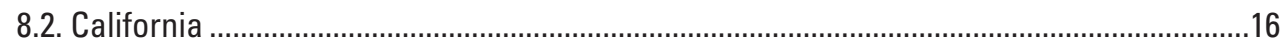

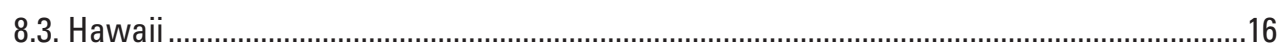

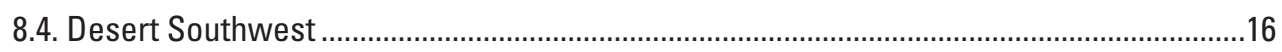

8.5. Midcontinent .............................................................................................................

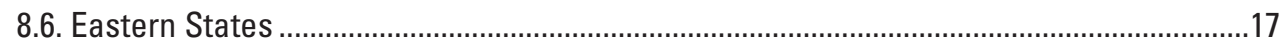

9. Conclusions

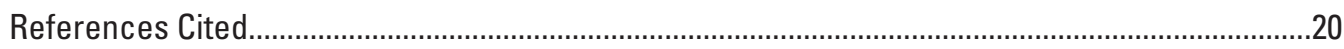

\section{Figures}

1. National map of mafic and ultramafic rocks in the United States....................................

2. Maps of stationary point sources of carbon dioxide emissions within 100 miles of mafic and ultramafic rocks in the Northwest and Southwest United States................6

3. Map of stationary point sources of carbon dioxide emissions and mafic rocks



4. Map of stationary point sources of carbon dioxide emissions within 100 miles of mafic and ultramafic rocks in the midcontinent United States ....................................18

5. Map of stationary point sources of carbon dioxide emissions within 100 miles of mafic and ultramafic rocks in the Eastern United States. 


\section{Tables}

1. Simplified carbonate mineralization reactions of common mafic and ultramafic minerals and basaltic glass ........................................................................................2

2. Summary of potential costs, benefits, and risks for carbon dioxide mineralization and saline storage methods.

\section{Conversion Factors}

International System of Units to U.S. customary units

\begin{tabular}{lcl}
\multicolumn{1}{c}{ Multiply } & By & \multicolumn{1}{c}{ To obtain } \\
\hline meter $(\mathrm{m})$ & Length & \\
kilometer $(\mathrm{km})$ & 3.281 & foot $(\mathrm{ft})$ \\
& 0.6214 & mile $(\mathrm{mi})$ \\
\hline square kilometer $\left(\mathrm{km}^{2}\right)$ & Area & \\
\hline & 0.3861 & square mile $\left(\mathrm{mi}^{2}\right)$ \\
\hline cubic meter $\left(\mathrm{m}^{3}\right)$ & Volume & \\
cubic kilometer $\left(\mathrm{km}^{3}\right)$ & 35.31 & cubic foot $\left(\mathrm{ft}^{3}\right)$ \\
& 0.2399 & cubic mile $\left(\mathrm{mi}^{3}\right)$ \\
\hline kilogram $(\mathrm{kg})$ & Mass & \\
metric ton $(\mathrm{t})[1,000 \mathrm{~kg}]$ & 2.205 & pound, avoirdupois $(\mathrm{lb})$ \\
metric ton $(\mathrm{t})[1,000 \mathrm{~kg}]$ & 1.102 & ton, short $[2,000 \mathrm{lb}]$ \\
\hline
\end{tabular}

Temperature in degrees Celsius $\left({ }^{\circ} \mathrm{C}\right)$ may be converted to degrees Fahrenheit $\left({ }^{\circ} \mathrm{F}\right)$ as follows:

$$
{ }^{\circ} \mathrm{F}=\left(1.8 \times{ }^{\circ} \mathrm{C}\right)+32
$$

\section{Datum}

Horizontal coordinate information is referenced to the North American Datum of 1983 (NAD 83). 


\section{Abbreviations}

$\begin{array}{ll}\text { CAMP } & \text { Central Atlantic magmatic province } \\ \mathrm{Ga} & \text { giga-annum, billion }\left(10^{9}\right) \text { years before the present (A.D. 1950) } \\ \mathrm{Gt} & \text { gigaton } \\ \mathrm{km} & \text { kilometer } \\ \mathrm{m} & \text { meter } \\ \mathrm{M} & \text { molar } \\ \mathrm{Ma} & \text { mega-annum, million }\left(10^{6}\right) \text { years before the present } \\ \text { (A.D. 1950) } \\ \mathrm{pCO} & \text { partial pressure of carbon dioxide } \\ \mathrm{ppm} & \text { part per million } \\ \mathrm{t} & \text { metric ton } \\ \text { USGS } & \text { U.S. Geological Survey }\end{array}$

\section{Chemical symbols used in this report}

$\begin{array}{ll}\mathrm{Ca} & \text { calcium } \\ \mathrm{CaOH} & \text { calcium hydroxide } \\ \mathrm{CO}_{2} & \text { carbon dioxide } \\ \mathrm{CO}_{3} & \text { carbonate } \\ \mathrm{Fe} & \text { iron } \\ \mathrm{FeO} & \text { iron (II) oxide } \\ \mathrm{Fe}_{2} \mathrm{O}_{3} & \text { iron (III) oxide } \\ \mathrm{H} & \text { hydrogen } \\ \mathrm{H}_{2} \mathrm{~S} & \text { hydrogen sulfide } \\ \mathrm{Mg} & \text { magnesium } \\ \mathrm{MgO} & \text { magnesium oxide } \\ \mathrm{MnO} & \text { manganese (II) oxide } \\ \mathrm{NaHCO} & \text { sodium bicarbonate } \\ \mathrm{NaCl}_{3} & \text { sodium chloride }\end{array}$




\section{Minerals discussed in this report}

$\begin{array}{ll}\mathrm{Al}_{2} \mathrm{Si}_{2} \mathrm{O}_{5}(\mathrm{OH})_{4} & \text { kaolinite } \\ \mathrm{CaAl}_{2} \mathrm{Si}_{2} \mathrm{O}_{8} & \text { anorthite } \\ \mathrm{CaCO}_{3} & \text { calcite } \\ \mathrm{Ca}(\mathrm{Fe}, \mathrm{Mg})\left(\mathrm{CO}_{3}\right)_{2} & \text { ankerite } \\ \mathrm{CaMg}\left(\mathrm{CO}_{3}\right)_{2} & \text { dolomite } \\ (\mathrm{Ca}, \mathrm{Mg}, \mathrm{Fe})_{2} \mathrm{Si}_{2} \mathrm{O}_{6} & \text { pyroxene } \\ (\mathrm{Ca}, \mathrm{Na})\left(\mathrm{Al}, \mathrm{Si}^{2} \mathrm{AlSi}_{2} \mathrm{O}_{8}\right. & \text { labradorite } \\ \mathrm{CaSiO} & \text { wollastonite } \\ \mathrm{FeCO}_{3} & \text { siderite } \\ \mathrm{FeCr}_{2} \mathrm{O}_{4} & \text { chromite } \\ \mathrm{FeS}_{2} & \text { pyrite } \\ \mathrm{MgCO}_{3} & \text { magnesite } \\ \left(\mathrm{Mg}_{2}, \mathrm{Fe}\right)_{2} \mathrm{SiO}_{4} & \text { olivine } \\ \mathrm{Mg}_{2} \mathrm{SiO}_{4} & \text { forsterite } \\ \mathrm{Mg}_{3} \mathrm{Si}_{2} \mathrm{O}_{5}(\mathrm{OH})_{4} & \text { chrysotile, antigorite, and lizardite pseudomorphs of serpentine } \\ \mathrm{Mg}_{3} \mathrm{Si}_{4} \mathrm{O}_{10}(\mathrm{OH})_{2} & \text { talc } \\ \mathrm{NaAlSi}_{3} \mathrm{O}_{8} & \text { albite } \\ \left(\mathrm{Na}_{1} \mathrm{Ca}_{\mathrm{Al}} \mathrm{Al}(\mathrm{Si}, \mathrm{All}) \mathrm{Si}_{2} \mathrm{O}_{6}\right. & \text { plagioclase } \\ \mathrm{SiO}_{2} & \text { quartz }\end{array}$




\title{
Carbon Dioxide Mineralization Feasibility in the United States
}

\author{
By Madalyn S. Blondes, Matthew D. Merrill, Steven T. Anderson, and Christina A. DeVera
}

\section{Abstract}

Geologic carbon dioxide $\left(\mathrm{CO}_{2}\right)$ storage is one of many methods for stabilizing the increasing concentration of $\mathrm{CO}_{2}$ in the Earth's atmosphere. The injection of $\mathrm{CO}_{2}$ in deep subsurface sedimentary reservoirs is the most commonly discussed method; however, the potential for $\mathrm{CO}_{2}$ leakage can create long-term stability concerns. This report discusses the feasibility of an alternative form of geologic $\mathrm{CO}_{2}$ storage: $\mathrm{CO}_{2}$ mineralization. In this method, $\mathrm{CO}_{2}$ reacts with rocks and minerals to form solid and stable carbonate rocks. New pilot projects and laboratory-based kinetics experiments have revealed that this method, both in situ and ex situ, may be a viable option for storage. In situ storage targets in-place rocks at the surface or subsurface. Ex situ storage targets industrial byproducts at the surface like mine tailings. Environmental risks include induced seismicity for in situ methods if pressure is not managed properly, as well as potential water and land use effects. However, there are fewer long-term $\mathrm{CO}_{2}$-leakage concerns for mineralization methods compared to saline storage methods and therefore potentially lower long-term monitoring costs. The costs and benefits of $\mathrm{CO}_{2}$ mineralization are compared to those of $\mathrm{CO}_{2}$ storage in saline reservoirs using estimates of pressure-limited dynamic storage capacity. This report highlights the regional potential of areas in the United States for in situ and ex situ storage, as well as their proximity to potential sources of $\mathrm{CO}_{2}$. Especially suitable targets include asbestos or other ultramafic mine tailings, in situ ultramafic rocks on the East and West Coasts, the Columbia River basalts in the Pacific Northwest, the Midcontinent Rift basalts in the midcontinent, and the basaltic Hawaiian Islands.

\section{Introduction}

The capture and storage of carbon dioxide $\left(\mathrm{CO}_{2}\right)$ has the potential to reduce $\mathrm{CO}_{2}$ concentrations in the Earth's atmosphere. At significant scales, $\mathrm{CO}_{2}$ storage may facilitate carbon-neutral electric power generation or provide other sectors with the ability to utilize existing industrial and mine waste. $\mathrm{CO}_{2}$ capture, the process of obtaining the $\mathrm{CO}_{2}$ to be stored, uses various industrial methods at point-source locations or, in the case of direct air capture, at any location.
$\mathrm{CO}_{2}$ can be isolated from the atmosphere by physical, biological, or geochemical means (Stephens and Keith, 2008). Capture processes are not the focus of this report, though they are mentioned for context where appropriate. The U.S. Geological Survey developed a method for assessing storage resources for physical $\mathrm{CO}_{2}$ storage, which is the injection of $\mathrm{CO}_{2}$ into saline reservoirs and depleted oil and gas fields, leading to buoyant and residual trapping of supercritical $\mathrm{CO}_{2}$ (U.S. Geological Survey Geologic Carbon Dioxide Storage Resources Assessment Team, 2013). When using physical trapping mechanisms in these types of reservoirs, $\mathrm{CO}_{2}$ leakage can be a concern because the buoyantly trapped liquefied gas in depleted oil and gas fields needs to be physically stopped from reaching overlying aquifers or the surface through fractures or permeable rock. The residually trapped gas in saline formations can be improperly engineered, become buoyant, and subsequently leak from the storage reservoir.

An alternative to $\mathrm{CO}_{2}$ storage as a fluid in sedimentary reservoirs is a geochemical method, $\mathrm{CO}_{2}$ mineralization, which occurs via carbonation reactions. This method is akin to the natural weathering process whereby rocks and minerals with high magnesium $(\mathrm{Mg})$, calcium $(\mathrm{Ca})$, or iron $(\mathrm{Fe})$ content react with $\mathrm{CO}_{2}$ to form a stable and inert carbonate rock. In this process, the $\mathrm{CO}_{2}$ is captured from the atmosphere or oceans during the reaction or supplied in a more concentrated form via injection into subsurface reservoirs or piping into surface industrial waste piles to significantly increase the rate of reaction. This report focuses primarily on the storage potential of mineralization reactions and does not discuss the capture or source of the $\mathrm{CO}_{2}$.

$\mathrm{CO}_{2}$ mineralization reactions can utilize various materials in different settings and include the in situ $\mathrm{CO}_{2}$ mineralization of basalts or ultramafic rocks (Matter and Kelemen, 2009; Gadikota, 2014; Gadikota, Matter, and others, 2014), the ex situ mineralization of alkaline mine tailings (Harrison and others, 2013; Gadikota, Natali, and others 2014; Gadikota and Park, 2014; Power and others, 2014; Pan and others, 2015), and reactions that produce other materials that have the potential to be used as mineral resources (Bobicki and others, 2012; Olajire, 2013). Kinetic experiments have shown fast reaction rates (review in Kelemen and others, 2011; more recent studies include Gadikota and others, 2014a), and recent pilot injection tests have shown greater than 95 percent $\mathrm{CO}_{2}$ 
mineralization in less than 2 years (Matter and others, 2016; McGrail and others, 2017). Building upon these results, the U.S. Department of Energy, National Energy Technology Laboratory, through its CarbonSAFE program, is funding a feasibility study on $\mathrm{CO}_{2}$ mineralization of the oceanic basalts in the offshore Cascadia basin (Goldberg, 2017). The United States has extensive resources of suitable rocks, and here we investigate how these experimental studies and pilot projects apply to the mineral resources in the United States and whether $\mathrm{CO}_{2}$ mineralization is an economically feasible technology.

Rock types suitable for large-scale $\mathrm{CO}_{2}$ mineralization are those that contain $\mathrm{Mg}^{2+}, \mathrm{Fe}^{2+}$, or $\mathrm{Ca}^{2+}$ cations. Suitable rocks that are abundant in the United States include the ultramafic rocks dunite, peridotite, and serpentinite and the mafic rock basalt. Dunite and peridotite consist principally of the magnesium iron silicate mineral olivine $\left(\left[\mathrm{Mg}, \mathrm{Fe}_{2} \mathrm{SiO}_{4}\right)\right.$, and serpentinite consists principally of the magnesium endmember serpentine-group pseudomorphs antigorite, lizardite, and chrysotile $\left(\mathrm{Mg}_{3} \mathrm{Si}_{2} \mathrm{O}_{5}[\mathrm{OH}]_{4}\right)$. Basalt consists principally of plagioclase (anorthite-albite, $\mathrm{CaAl}_{2} \mathrm{Si}_{2} \mathrm{O}_{8}-\mathrm{NaAlSi}_{3} \mathrm{O}_{8}$ ), pyroxene minerals $\left([\mathrm{Ca}, \mathrm{Mg}, \mathrm{Fe}]_{2} \mathrm{Si}_{2} \mathrm{O}_{6}\right)$, and olivine. Locally, very quickly chilled basaltic lava forms amorphous glass, which has available $\mathrm{Mg}^{2+}, \mathrm{Fe}^{2+}$, and $\mathrm{Ca}^{2+}$ cations, rather than a crystalline rock. Although these minerals and basaltic glasses can vary in composition, we show here examples of only the most reactive simple endmember reactions to form carbonate minerals (table 1). We show the example reactions as simplified one-step processes; however, carbonate mineralization of silicates can occur by several multistep methods. In some natural environments and engineered settings, a pH-swing process is used, which is a three-step reaction: (1) hydration of $\mathrm{CO}_{2}$ to release hydrogen $\left(\mathrm{H}^{+}\right)$and carbonate $\left(\mathrm{CO}_{3}{ }^{2-}\right)$ ions into solution; (2) mineral dissolution to release $\mathrm{Mg}^{2+}, \mathrm{Fe}^{2+}$, and $\mathrm{Ca}^{2+}$ cations into solution; and (3) ionic reactions to form insoluble carbonates (Gadikota, Swanson, and others, 2014). Alternatively, water dissolved into liquid or supercritical $\mathrm{CO}_{2}$ is also highly reactive with $\mathrm{Mg}^{2+}-, \mathrm{Fe}^{2+}$-, and $\mathrm{Ca}^{2+}$-bearing materials (McGrail and others, 2009).

The feasibility of $\mathrm{CO}_{2}$ mineralization in the United States is a function of many factors. First, it is necessary to know the location and abundance of the suitable rock types and the specific mineralogy and chemistry of these rocks. This is addressed in figure 1 (which shows location and areal extent of the appropriate rock types) and in greater detail in section 8 of this report, "Regional Carbon Dioxide Mineralization Feasibility in the United States." It is then imperative to understand the extent and timing of the carbonation reactions, which are dependent on the kinetics of reaction for different minerals, as well as variables like temperature, pressure, the addition of catalysts, and the phase of $\mathrm{CO}_{2}$. Reaction rate experiments are discussed in section 2, "Reaction Rate Experiments and Models." The extent and timing of carbonate formation are also highly dependent on the surface area of reaction. The surface area of reaction is itself a function of the porosity and permeability of the rock for in situ $\mathrm{CO}_{2}$ mineralization, or the grain size of crushed rock for ex situ $\mathrm{CO}_{2}$ mineralization. These properties are addressed in sections 3 and 4, "In Situ Carbon Dioxide Mineralization" and "Ex Situ Carbon Dioxide Mineralization," respectively. To test

Table 1. Simplified carbonate mineralization reactions of common mafic and ultramafic minerals and basaltic glass.

\begin{tabular}{|c|c|c|}
\hline Mineral or phase & Reaction & Notes \\
\hline Serpentine & $\begin{array}{l}\mathrm{Mg}_{3} \mathrm{Si}_{2} \mathrm{O}_{5}(\mathrm{OH})_{4}+3 \mathrm{CO}_{2} \rightarrow 3 \mathrm{MgCO}_{3}+2 \mathrm{SiO}_{2}+2 \mathrm{H}_{2} \mathrm{O} \\
(\text { serpentine [for example, antigorite] })+(\text { carbon dioxide }) \\
\quad \rightarrow(\text { magnesite })+(\text { quartz })+(\text { water })\end{array}$ & $\begin{array}{l}\text { Serpentine is a hydrated form of olivine found in } \\
\text { serpentinite rocks. }\end{array}$ \\
\hline Plagioclase & $\begin{array}{l}\mathrm{Ca}_{2} \mathrm{Al}_{2} \mathrm{Si}_{2} \mathrm{O}_{8}+\mathrm{CO}_{2}+2 \mathrm{H}_{2} \mathrm{O} \rightarrow \mathrm{CaCO}_{3}+\mathrm{Al}_{2} \mathrm{Si}_{2} \mathrm{O}_{5}(\mathrm{OH})_{4} \\
\text { (plagioclase [anorthite }])+(\text { carbon dioxide })+(\text { water }) \\
\quad \rightarrow \text { (calcite) }+(\text { kaolinite })\end{array}$ & $\begin{array}{l}\text { Plagioclase is the most abundant mineral in } \\
\text { basaltic rocks. Anorthite is the calcium end- } \\
\text { member. }\end{array}$ \\
\hline
\end{tabular}


whether $\mathrm{CO}_{2}$ mineralization techniques will work in natural settings, multiple large-scale pilot tests have been undertaken, all by in situ injection of $\mathrm{CO}_{2}$ into basaltic rocks. These tests are discussed in section 5, "Pilot Projects." To evaluate the feasibility of $\mathrm{CO}_{2}$ mineralization, it is also important to discuss environmental effects, as well as economic constraints and risk, which are sections 6 and 7, respectively. Lastly, in section 8, "Regional Carbon Dioxide Mineralization Feasibility in the United States," we take a regional approach to understanding the strengths and weaknesses of different techniques of $\mathrm{CO}_{2}$ mineralization, taking into account the availability of $\mathrm{CO}_{2}$ from industrial sources.

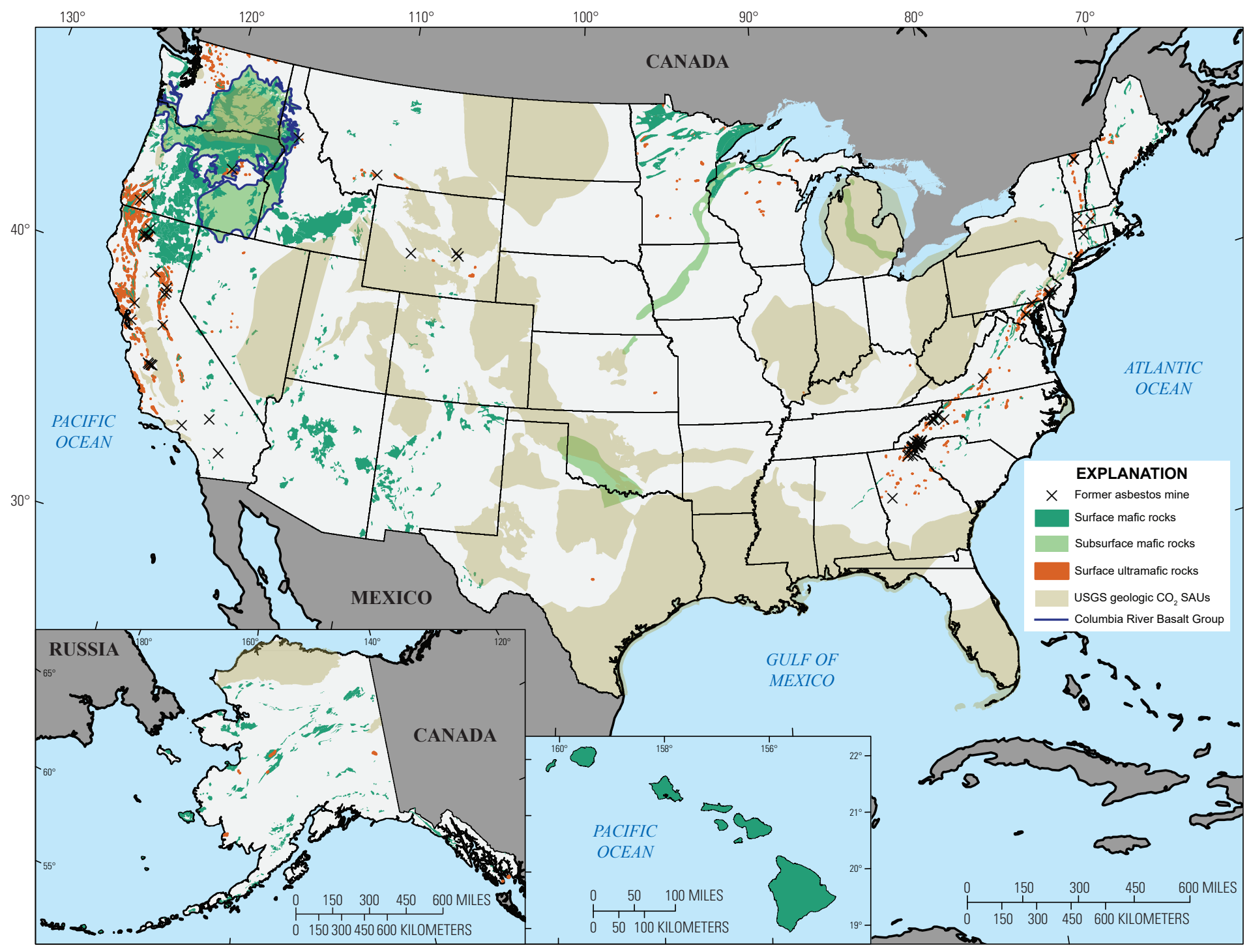

Figure 1. National map of mafic and ultramafic rocks in the United States. Geologic data were compiled and, in some instances, simplified from Lambert and others (1988), Ojakangas and others (2001), Reed and others (2005), Sherrod and others (2007), Garrity and Soller (2009), Krevor and others (2009), and Barry and others (2013). Outlines of ultramafic-rock polygons were used to increase visibility. Asbestos mines were compiled from past producing mines described in Van Gosen (2006a,b; 2007a; 2008; 2010) and Van Gosen and Clinkenbeard (2011). U.S. Geological Survey (USGS) geologic carbon dioxide $\left(\mathrm{CO}_{2}\right)$ storage assessment units (SAUs) were defined in the USGS national assessment of geologic $\mathrm{CO}_{2}$ storage resources (U.S. Geological Survey Geologic Carbon Dioxide Storage Resources Assessment Team, 2013) to estimate $\mathrm{CO}_{2}$ storage potential in saline reservoirs within sedimentary basins. The western Aleutian Islands in Alaska that do not contain relevant rock types are not shown. Base map was compiled from data from Environmental Systems Research Institute, Inc. (2007a,b) and Jarvis and others (2008). 


\section{Reaction Rate Experiments and Models}

To understand whether carbonate mineralization is technically and economically feasible for storing $\mathrm{CO}_{2}$ on reasonable time scales and to large extents, it is important to understand the rates of reaction for the relevant minerals. Kinetic dissolution and precipitation experiments on minerals (olivine and serpentine) and reactive whole rocks (basalt, serpentinite, peridotite, and dunite) have been performed for varying conditions, such as using a range of grain sizes, whole rock versus crushed samples, catalysts, different phases of $\mathrm{CO}_{2}$ (aqueous versus supercritical), and a range of experimental designs.

$\mathrm{CO}_{2}$ mineralization is commonly envisioned as a twostep process consisting of the dissolution of $\mathrm{Mg}-, \mathrm{Ca}-$, and Fe-bearing silicates (or basaltic glass) and the subsequent precipitation of $\mathrm{Mg}, \mathrm{Ca}$, and Fe carbonates. Dissolution is often thought to be the rate-limiting step; therefore, the kinetics of $\mathrm{CO}_{2}$ mineralization for different minerals have been compared mostly by measuring the dissolution rates for different materials under varying conditions (Kelemen and others, 2011). Aside from the relatively uncommon mineral wollastonite $\left(\mathrm{CaSiO}_{3}\right)$, olivine, particularly the $\mathrm{Mg}$ endmember forsterite, has the fastest dissolution rates and requires the least mass to store a given mass of carbon (Oelkers and others, 2008). Much of the experimental work on determining reaction rates for $\mathrm{CO}_{2}$ mineralization has thus been done on olivine; for example, analyzing the effects of the partial pressure of $\mathrm{CO}_{2}\left(\mathrm{pCO}_{2}\right)$, temperature, $\mathrm{pH}$, dissolved sodium bicarbonate $\left(\mathrm{NaHCO}_{3}\right)$, and dissolved sodium chloride $(\mathrm{NaCl})$ (O'Connor and others, 2004; Hänchen and others, 2006; Chizmeshya and others, 2007; Prigiobbe and others, 2009; Gadikota, Matter, and others, 2014) and the addition of catalysts to increase dissolution rates (for example, Krevor and Lackner, 2011). Pyroxene in basalts has also been shown to be an important source of divalent cations for carbonation (Wells and others, 2017).

Other studies have focused on processes other than dissolution that can affect the rate of $\mathrm{CO}_{2}$ mineralization. Saldi and others (2012) showed that under certain conditions magnesite precipitation can be three to four orders of magnitude slower than olivine dissolution and is the rate-limiting step. The formation of a passivating silica $\left(\mathrm{SiO}_{2}\right)$ layer on mineral grain boundaries may inhibit dissolution and therefore restrict carbon mineralization (Béarat and others, 2006; Daval and others, 2011). However, precipitation rates increase in high- $\mathrm{NaHCO}_{3}$ and high-pCO $\mathrm{CO}_{2}$ fluids, perhaps because the passivation layers do not have a strong influence on inhibiting carbon mineralization in these environments (Chizmeshya and others, 2007; Kelemen and others, 2011). Direct carbon mineralization studies by Gadikota, Matter, and others (2014) showed that more than 70 percent of olivine was converted to magnesium carbonate in 3 hours by reacting in a fluid bearing 1.0-molar $(M) \mathrm{NaCl}$ and $0.64-M \mathrm{NaHCO}_{3}$ in the temperature range of 150 to 200 degrees Celsius.

Serpentine dissolution kinetics are significantly slower than those of olivine (Park and others, 2003; O'Connor and others, 2004; Park and Fan, 2004; Daval and others, 2013) unless serpentine is heat treated (Gerdemann and others, 2007). In addition, it is possible to engineer a pH-swing process to optimize dissolution of serpentine at low $\mathrm{pH}$ and precipitation at higher $\mathrm{pH}$ (Park and Fan, 2004). Serpentine and serpentinites are much more mineralogically variable than olivine and peridotites, so a wide range of materials and techniques have been used in kinetic experiments. Experiments on serpentine have shown that both fast and slow dissolution regimes may exist (Gadikota, Swanson, and others, 2014). The $\mathrm{CO}_{2}$ mineralization of existing serpentine mine tailings, including asbestos mine tailings, is discussed in section 4, "Ex Situ Carbon Dioxide Mineralization."

Basalt mineralization kinetics can be measured on whole rocks, volcanic glass, or plagioclase crystals that are the dominant phase of basalt. Of the phases analyzed by Oelkers and others (2008), plagioclase has the slowest dissolution rates and requires the most mass to store a given mass of carbon. Basaltic glass dissolution, however, is faster than the dissolution of serpentine, pyroxenes, and even olivine under some conditions (Oelkers and others, 2008; Kelemen and others, 2011). Schaef and others (2009) reacted mildly acidic, $\mathrm{CO}_{2}$-saturated water with rock samples collected from flood basalt provinces around the world, and they found that $\mathrm{CO}_{2}$ was converted to carbonates in all samples. The proportion of volcanic glass was positively correlated with the reaction rate and was the dominant controlling factor. Experiments using supercritical $\mathrm{CO}_{2}$ showed faster mineralization rates than those using aqueous $\mathrm{CO}_{2}$ (Schaef and others, 2011). Though the rates and extents of reactions for basalts are less than those for olivine and serpentine, basaltic material is more widely distributed across the near surface and therefore is potentially more available for mineralization.

Reaction rates for minerals found in mafic and ultramafic rocks can be optimized by adjusting the temperature, pressure, and $\mathrm{pCO}_{2}$; using additives; and crushing rock to generate carbonates in both in situ and ex situ settings within a few years. These reaction rates are much faster than the $\mathrm{CO}_{2}$ mineralization time scales (thousands of years) considered in earlier review papers that compared the implementation feasibility of various $\mathrm{CO}_{2}$ storage methods (Benson and others, 2005, fig. 5.9). In section 5, "Pilot Projects," we describe two pilot projects using basalts that have shown nearly complete mineralization of injected $\mathrm{CO}_{2}$ in less than 2 years (Matter and others, 2016; McGrail and others, 2017), though they have injected relatively small amounts of $\mathrm{CO}_{2}$ compared to the reservoir volumes. Continued work on these projects may provide more applicable information on reaction rates as more $\mathrm{CO}_{2}$ is injected. 


\section{In Situ Carbon Dioxide Mineralization}

One potential method to store $\mathrm{CO}_{2}$ through mineralization is by injecting $\mathrm{CO}_{2}$ fluids into subsurface rocks without first mining or crushing the rocks. This process is known as in situ $\mathrm{CO}_{2}$ mineralization and is possible in basalts and ultramafic rocks. Though the difference between basalts and ultramafic rocks, from a chemical standpoint, is a small change in the amount of $\mathrm{Mg}$ and Fe relative to silicon (Si), in general, these rock types have very different emplacement origins. The different origins lead to distinct textures, fracture densities, and porosities, which, in addition to the abundance of mafic elements, results in varied mechanisms of reaction. Most mafic rocks in the United States are extrusive igneous lava flows or near-surface sills and dikes, which exhibit high porosity and permeability in their vesicular flow boundaries and fractures (Reidel and others, 2002). Mafic rocks have a total mafic component (magnesium oxide [MgO], iron [II] oxide [FeO], manganese [II] oxide [MnO], and iron [III] oxide $\left[\mathrm{Fe}_{2} \mathrm{O}_{3}\right]$ ) content of 15 to 28 weight percent and $\mathrm{SiO}_{2}$ content of 46 to 54 weight percent (Sen, 2014).

Ultramafic rocks in the United States are generally intrusive or deeply buried igneous or metamorphic rocks. These rocks have a higher total mafic component content of 35 to 46 weight percent and lower $\mathrm{SiO}_{2}$ content of 42 to 48 weight percent (Sen, 2014). Overall, ultramafic rocks exhibit more variable reactivity than mafic rocks: ultramafic rocks contain the most energetically favorable minerals for reaction with $\mathrm{CO}_{2}$, but they generally have lower porosity and permeability and wide-ranging crystal sizes. Though more common in ultramafic rocks, if mafic or ultramafic rocks contain minerals that have been naturally carbonated, they become minimally reactive. The reactivities of olivine are much higher than those of alumino-silicate-bearing minerals and rocks (such as basalt, labradorite, and anorthosite) (Gadikota, 2014).

\subsection{Mafic Rocks (Basalt)}

Mafic rocks, particularly large basaltic lava flows, offer voluminous potential sinks for $\mathrm{CO}_{2}$ mineralization (Gislason and Oelkers, 2014). Abundant $\mathrm{Mg}^{2+}$ and $\mathrm{Ca}^{2+}$ cations are available for reaction in basaltic glass, plagioclase crystals, and olivine crystals (table 1). Large-volume basalts exist in the Columbia River Basalt Group, a continental flood-basalt province primarily in Washington, Oregon, and southern Idaho (figs. 1 and $2 A$ ) that erupted between 17 and 6 million years ago (Ma) (Tolan and others, 1989). These lava flows have abundant fractures as well as high-permeability and -porosity flow boundaries, interbedded with low-porosity flow interiors (Reidel and others, 2002). The high-porosity flow boundaries create a large surface area of reaction to form carbonates, and the low-porosity flow interiors act as vertical barriers to keep mineralization in the preferred zones (McGrail and others,
2006). The Columbia River basalts have been the focus of many studies on $\mathrm{CO}_{2}$ mineralization (such as McGrail and others, 2006; Schaef and others, 2009). Estimates of storage potential range from 10 metric gigatons $(\mathrm{Gt})$ to $100 \mathrm{Gt}$ (McGrail and others, 2006; Gislason and others, 2010). Recent results from a pilot project at the Wallula basalt pilot project in Washington (McGrail and others, 2017) are described in section 5 .

Older surface volcanic and subsurface intrusive basalts exist in the United States, including the Keweenawan Supergroup basalts (that formed at $1.1 \mathrm{Ga}$, or 1.1 billion years before the present) in the Midcontinent Rift (Cannon and others, 1989) and the Central Atlantic magmatic province (CAMP) basalts (that formed at $200 \mathrm{Ma}$, or 200 million years before the present) in Mesozoic rift basins both onshore and offshore of the East Coast (Goldberg and others, 2010). These older basalts, particularly those buried at depth, are likely less favorable for storage than younger surface lava flows because metamorphic and metasomatic reactions at depth generally reduce porosity and permeability and therefore reduce the availability for carbonation.

Deep-sea basalts, which are the main constituent of oceanic crust, are another potential target for $\mathrm{CO}_{2}$ mineralization in basalts. At oceanic ridges, basalt is generated by sea-floor spreading and is highly fractured and permeable. Older basalts that are farther from spreading ridges lose porosity because of chemical weathering (Goldberg and Slagle, 2009). The estimated storage potential in basalts flanking the Juan de Fuca Ridge in an area roughly 200 to 1,000 kilometers (km) off the coast of the Pacific Northwest of the United States is 134 to $668 \mathrm{Gt} \mathrm{CO}_{2}$ (Goldberg and Slagle, 2009). Other oceanic basalts include most of the Hawaiian Island chain and therefore the entire State of Hawaii (fig. 3). The recent CarbFix pilot project in Iceland (Matter and others, 2016), described in more detail in section 5, can be used as an analog for $\mathrm{CO}_{2}$ storage in the Hawaiian Islands.

\subsection{Ultramafic Rocks (Dunite, Peridotite, and Serpentinite)}

Unlike basalts, which have relatively homogenous whole-rock compositions, ultramafic rocks are compositionally heterogeneous and have highly variable porosity and permeability. Most ultramafic rocks near the surface are, or once were, peridotites or dunites that originated from the upper mantle beneath oceanic spreading ridges and were obducted onto convergent plate margins (Coleman, 1977). Since emplacement, these rocks have undergone variable levels of retrograde metamorphism (Kelemen and Hirth, 2012). Retrograde metamorphism can include hydration to form serpentinite and (or) carbonation to form retrogrademetamorphic assemblages that include $\mathrm{Mg}$ carbonates, commonly carbonate-veined peridotites, soapstone (magnesite and talc), and listvenite (magnesite and quartz). Dunite, peridotite, and serpentinite are all ultramafic targets for $\mathrm{CO}_{2}$ 
$\boldsymbol{A}$

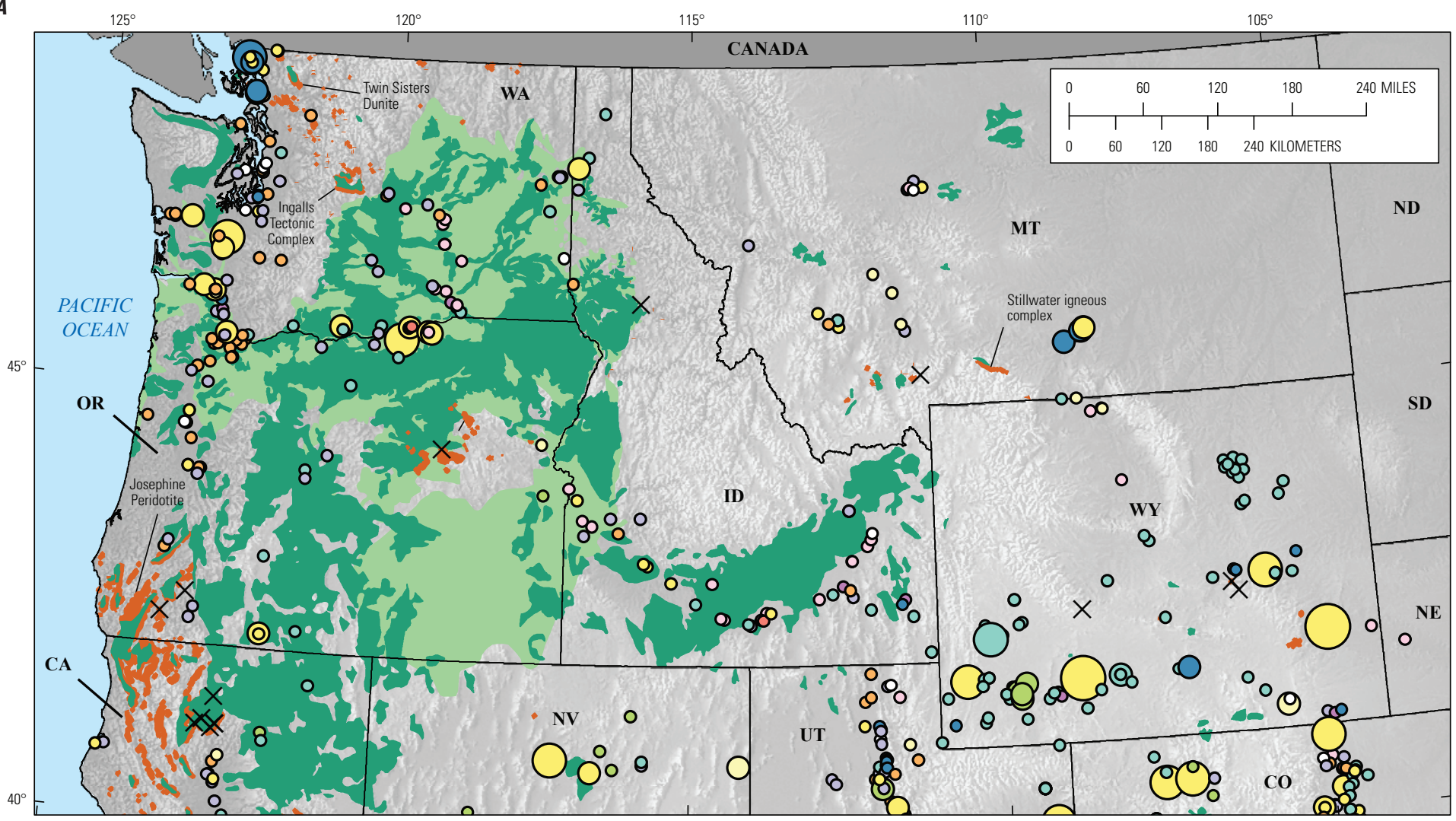

EXPLANATION

Stationary $\mathrm{CO}_{2}$ source emissions (metric tons per year)

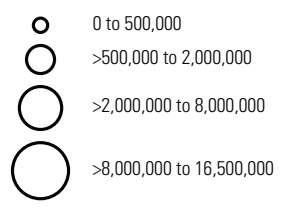

$\mathrm{CO}_{2}$ emission point source

Geologic target for $\mathrm{CO}_{2}$ mineralization

$\begin{array}{ll}\text { ○ Agricultural processing } & \text { ○ Industrial } \\ \text { ○ Cement plant } & \text { ○ Mining } \\ \text { ○ Electricity } & \text { ○ Petroleum/Natural gas } \\ \text { ○ Ethanol } & \text { ○ Refineries/Chemical } \\ \text { ○ Fertilizer } & \text { ○ Waste management } \\ & \text { ○ Unclassified }\end{array}$

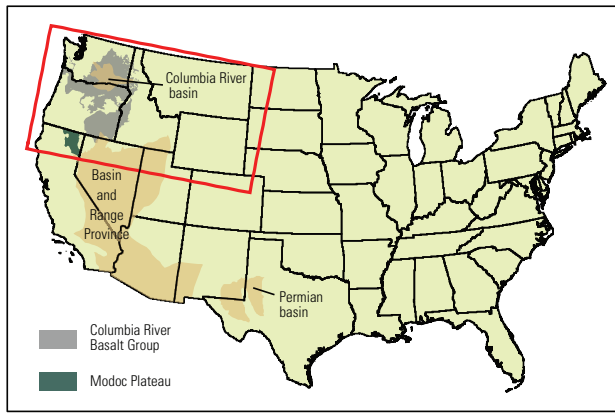

Figure 2. Maps of stationary point sources of carbon dioxide $\left(\mathrm{CO}_{2}\right)$ emissions within 100 miles (160 kilometers) of mafic and ultramafic rocks in the Northwest $(A)$ and Southwest $(B)$ United States. Geologic data were compiled and, in some instances, simplified from Reed and others (2005), Garrity and Soller (2009), Krevor and others (2009), and Barry and others (2013). Outlines of ultramafic-rock polygons were used to increase visibility. Asbestos mines, also shown, were compiled from past producing mines described in Van Gosen $(2007$ a, 2008, 2010) and Van Gosen and Clinkenbeard (2011). $\mathrm{CO}_{2}$ point-source data are from National Energy Technology Laboratory Carbon Storage Atlas (2015). Base maps were compiled from data from Environmental Systems Research Institute, Inc. (2007a,b) and Jarvis and others (2008). Modoc Plateau outline is from Fram and Shelton (2014). Central Valley outline is from Faunt (2012). 
B

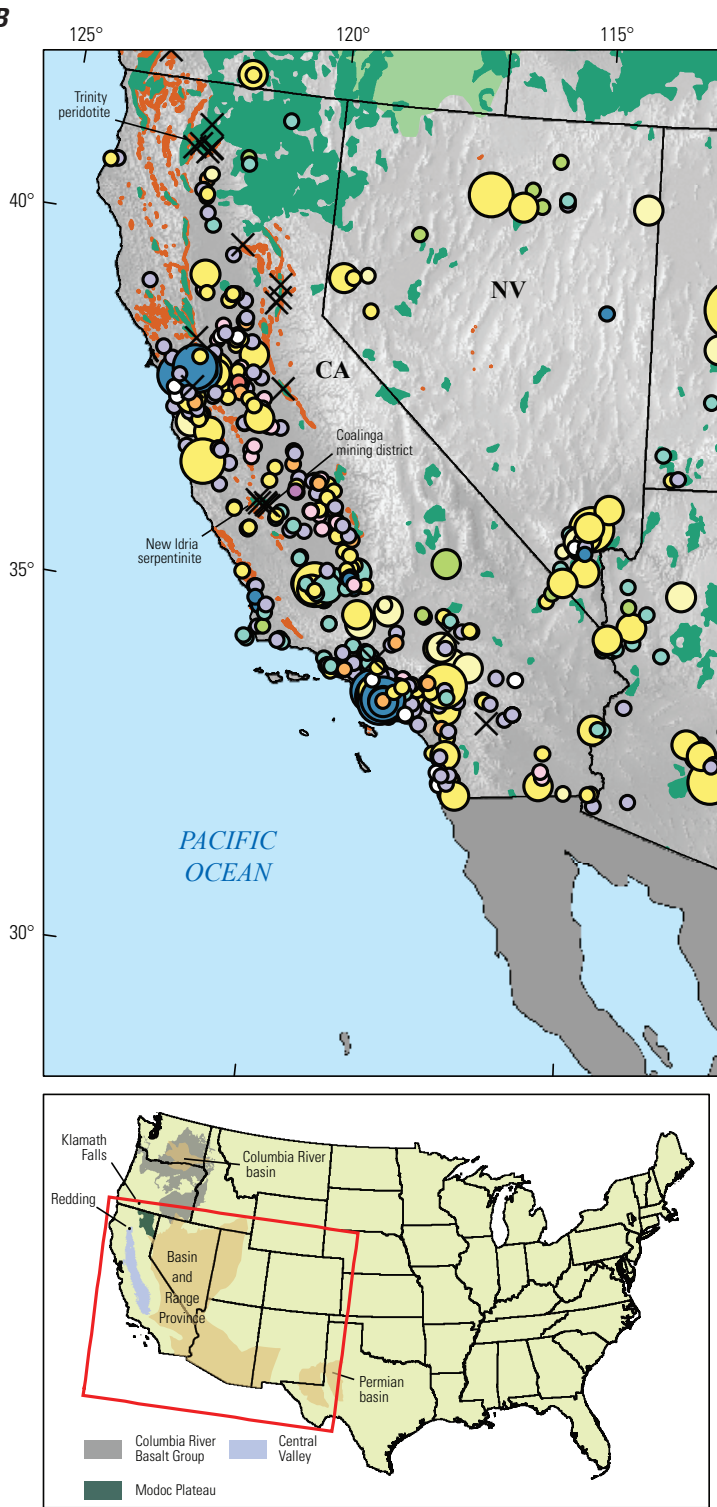

\section{EXPLANATION}

Stationary $\mathrm{CO}_{2}$ source emissions (metric tons per year)

- 0 to 500,000

$>500,000$ to $2,000,000$

$>2,000,000$ to $8,000,000$

$\bigcirc$

$>8,000,000$ to $16,500,000$

$\mathrm{CO}_{2}$ emission point source

○ Agricultural processing

O Cement plant

○ Electricity

O Ethanol

○ Fertilizer

○ Industrial

○ Mining

O Petroleum/Natural gas

- Refineries/Chemical

O Waste management

○ Unclassified

Geologic target for $\mathrm{CO}_{2}$ mineralization

Surface mafic rocks

Subsurface mafic rocks

Surface ultramafic rocks

Former asbestos mine

Figure 2. - Continued. 


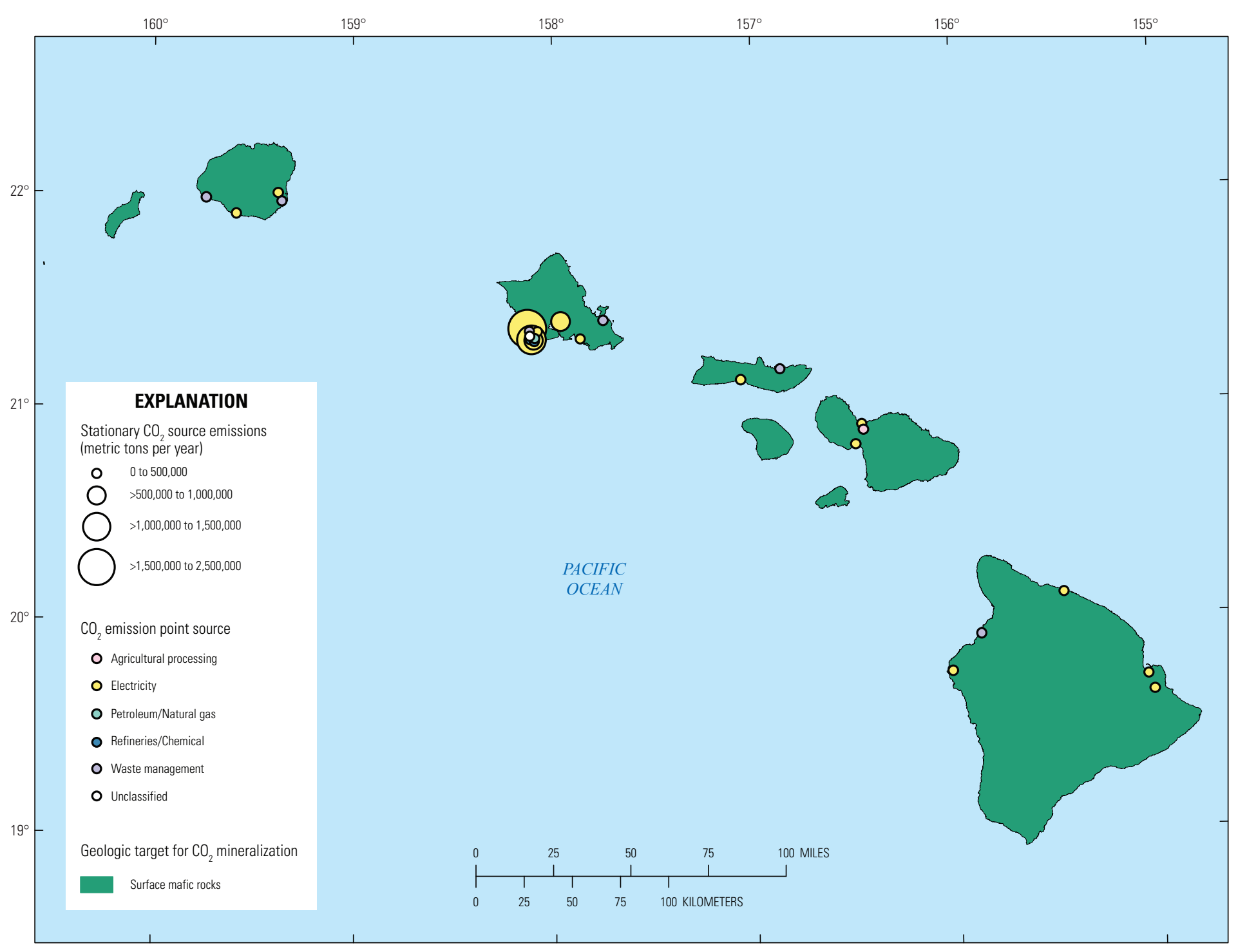

Figure 3. Map of stationary point sources of carbon dioxide $\left(\mathrm{CO}_{2}\right)$ emissions and mafic rocks in the State of Hawaii. Geologic data were compiled and, in some instances, simplified from Sherrod and others (2007). $\mathrm{CO}_{2}$ point-source data are from National Energy Technology Laboratory Carbon Storage Atlas (2015). Base map was compiled from data from Environmental Systems Research Institute, Inc. (2007a).

mineralization. Dunite and peridotite are typically partially hydrated (serpentinized) but still contain tens of percent $\mathrm{Mg}$ olivine. Fully hydrated peridotites (serpentinites) contain abundant Mg-serpentine minerals. Dunites, peridotites, and serpentinites that have naturally reacted with $\mathrm{CO}_{2}$ to form soapstone or listvenite are not ideal targets for further $\mathrm{CO}_{2}$ storage, particularly if that reaction has gone to completion. In the United States, ultramafic rocks suitable for $\mathrm{CO}_{2}$ storage are generally found along the East and West Coasts in orogenic settings or as layered intrusions in intracratonic settings such as the Stillwater igneous complex in Montana (Goff and Lackner, 1998; Goff and others, 2000; Krevor and others, 2009).
To date, there have been no field-scale pilot projects of in situ $\mathrm{CO}_{2}$ storage in ultramafic rocks, but one can gauge the feasibility of this technique by studying the laboratory reaction-rate experiments described in section 2 and particularly by investigating natural analogs (Matter and Kelemen, 2009; Kelemen and others, 2011). By examining natural settings where $\mathrm{CO}_{2}$ has reacted with ultramafic rocks in near-surface environments, we can estimate reaction rates, extents of reaction, changes in porosity and permeability, and potential risks. It is particularly important to determine permeability and porosity changes in ultramafic outcrops because the reaction of $\mathrm{CO}_{2}$ with olivine or serpentine to form 
magnesite is both an exothermic and volume-increasing reaction. Whether the volume expansion inhibits or enhances the carbonation reaction is an open question. A laboratory-scale study showed that increasing magnesite formation reduced the accessible pore space in the olivine precursor (Gadikota, Matter, and others, 2014). This volume expansion may either clog the existing pore space, restricting the surface area of reaction such that the carbonation reaction ceases, or it may increase pore pressures beyond the fracture pressure, creating new fractures, greater permeability, and a self-propagating reaction-driven cracking system with ever increasing surface area of reaction controlled by $\mathrm{CO}_{2}$ injection (Rudge and others, 2010; Kelemen and Hirth, 2012; Zhu and others, 2016). Lisabeth and others (2017) postulated that the propagating reaction is a function of chemo-mechanical coupling, whereby stress-induced dissolution leads to a reduction in permeability. Following mineral carbonation, the change in pore space in any given setting is dependent on a number of variables, including the pressure and temperature of the system and the mineralogy of the rock.

Examples of ultramafic rocks that have naturally reacted with $\mathrm{CO}_{2}$ to form carbonates are in most convergent-margin settings where ophiolites exist. The Samail ophiolite in Oman and the United Arab Emirates shows evidence of both high-temperature mineralization in the listvenites and lowtemperature mineralization in the carbonate veins (Kelemen and others, 2011; Falk and Kelemen, 2015). The fractures that contain the listvenite assemblage of magnesite and quartz are randomly oriented, suggesting that the fracturing is not tectonically driven but rather is derived from carbonate mineralization reaction-driven cracking (Falk and Kelemen, 2015). Listvenites in Atlin, British Columbia, Canada, show that the carbonation of serpentinites extends tens of meters from $\mathrm{CO}_{2}$-filled fractures. Though the intermediate reaction to soapstone generates increased fracture permeability, the full reaction to magnesite and quartz significantly reduces the porosity by filling the existing pore space, ending the ability to react more rock with $\mathrm{CO}_{2}$ unless new fractures form (Hansen and others, 2005). Bruni and others (2002) and Cipolli and others (2004) analyzed natural springs in Genova, Italy, where high-pH, calcium hydroxide $(\mathrm{CaOH})$ spring waters are indicative of serpentinite aquifers at depth that have reacted with $\mathrm{CO}_{2}$ to form magnesite and chalcedony $\left(\mathrm{SiO}_{2}\right)$ or amorphous silica (also $\mathrm{SiO}_{2}$ ). Their models showed a reduction of effective porosity in the aquifers, which was more pronounced if amorphous silica precipitated rather than chalcedony. Serpentinite ophiolite fragments in Norway also show evidence of a large-scale carbonation reaction to soapstone (magnesite and talc) and listvenite (magnesite and quartz) (Beinlich and others, 2012). Though carbonation reaction rates are slower in serpentinite than in peridotite, the resulting volume expansion is lesser, so there is a reduced possibility of clogging the pore space. Porosimitry and mass-balance calculations showed that the conversion of serpentine to soapstone proceeded isovolumetrically, and the reaction fronts were controlled by the $\mathrm{CO}_{2}$ supply from alteration of the surrounding schist, not by a reduction in porosity (Beinlich and others, 2012). Other examples include ultramafic-rock-hosted magnesite and talc deposits in Vermont (Robinson and others, 2006), the Advocate ophiolite to the northeast in Newfoundland, Canada (Bédard and Escayola, 2010), and the listvenites found in the Sartohay and Luobusa ophiolites in China (Robinson and others, 2005).

\section{Ex Situ Carbon Dioxide Mineralization}

Another possible method to store $\mathrm{CO}_{2}$ through mineralization is by ex situ reaction with crushed material at the surface. Available, crushed solid reactants include mine tailings derived from mafic or ultramafic rocks and alkaline industrial wastes (Gerdemann and others, 2007; Renforth and others, 2011; Kirchofer and others, 2013; Power and others, 2013; Gadikota, Matter, and others, 2014; Power and others, 2014). When using crushed material instead of whole rock, the surface area of reaction is greater; therefore, the kinetics of the reaction are significantly faster, but the volume of resource available for carbonate mineralization is orders of magnitude less than that of in situ resources like basalts and ultramafic rocks. The faster reactions and readily available material, however, may prove to be more economic on small scales when attempting to create carbon-neutral electric powerplants or utilizing existing mine-waste material. The cost per metric ton $(\mathrm{t})$ of $\mathrm{CO}_{2}$ stored would be smaller for ultramafic rocks with abundant $\mathrm{Mg}^{2+}$ and $\mathrm{Ca}^{2+}$ cations available for reaction and larger for lithologies with fewer $\mathrm{Mg}^{2+}$ and $\mathrm{Ca}^{2+}$ cations, such as felsic rocks. Depending upon demand and cost, rocks could be mined and crushed for the specific purpose of ex situ carbon mineralization. If mining is done specifically for this process, however, there will be an increase in surface impacts, such as increased noise, truck traffic, and visibility of the mining operation and carbonate piles.

\subsection{Carbon Dioxide Mineralization of Mine Tailings}

Mafic and ultramafic mine tailings are generated during the extraction and production of asbestos, chromite, diamond, nickel, platinum-group metals, and talc. These tailings react passively with atmospheric $\mathrm{CO}_{2}$ to produce carbonate minerals under natural conditions (Levitan and others, 2009; Wilson, Dipple, and others, 2009; Wilson, Raudsepp, and others, 2009; Pronost and others, 2012). Piping $\mathrm{CO}_{2}$ into the tailings and designing tailings storage methods to favor increased reactions would significantly increase the carbonation reaction rate (Gerdemann and others, 2007; Harrison and others, 2013; Power and others, 2013; Power and others, 2014). Power and others (2014) and references therein reviewed strategies to increase tailings-hosted reaction rates, including bioleaching 
of $\mathrm{Mg}$ silicates, increasing the $\mathrm{CO}_{2}$ supply through heterotrophic oxidation, using bioreactors to induce precipitation of carbonate minerals, and other methods.

The most well-known and largest asbestos deposits in the United States and worldwide are those that have replaced or formed by metasomatic alteration of an ultramafic rock (Ross and Nolan, 2003; Van Gosen, 2007b). Most commonly, the host ultramafic rock is a dunite, peridotite, amphibolite, pyroxenite, or the hydrated equivalent, serpentinite. In the United States, large amounts of mine wastes composed of ultramafic rocks and serpentinite rock have been left behind at abandoned asbestos mines, which could offer potential sites and sources of material for pilot projects of ex situ $\mathrm{CO}_{2}$ mineralization. Prominent examples occur in Vermont and California (Krevor and others, 2009), such as the abandoned Belvidere asbestos mine near Eden Mills in northern Vermont and the former asbestos mines of the Coalinga mining district in San Benito and Fresno Counties of west-central California.

\subsection{Carbon Dioxide Mineralization of Alkaline Industrial Wastes}

In addition to mining, many industrial processes also generate high-surface-area materials that could be potential sources of $\mathrm{Mg}^{2+}, \mathrm{Fe}^{2+}$, and $\mathrm{Ca}^{2+}$ cations. Industrial byproducts such as fly ash, cement kiln dust, and iron and steel slag have been evaluated for their mineral carbonation potential (Huijgen and Comans, 2005; Gerdemann and others, 2007; Renforth and others, 2011; Gadikota, Matter, and others, 2014). Kirchofer and others (2013) found that 7.6 million metric tons of $\mathrm{CO}_{2}(0.1$ percent of U.S. total annual emissions) could be prevented or sequestered each year using these byproducts. Gerdemann and others (2007) noted that the small amount of total byproducts would restrict their use to niche applications where a hazardous waste could be remediated by carbonation or to help a company meet emissions targets.

Brines also have high concentrations of cations that could react to form carbonates. As a $\mathrm{CO}_{2}$-storage solution, the injection of a brine and $\mathrm{CO}_{2}$ mixture into disposal wells could create scaling within the well and also mineralize the pore space at depth, creating pressure-management issues. However, there might be economic uses for the carbonates formed in reactions using salts from desalination processes. Haywood and others (2001) provided some discussion of these potential reactions.

\section{Pilot Projects}

Subsurface carbonate mineralization following the injection of $\mathrm{CO}_{2}$ into mafic rocks has been demonstrated in two locations using different injection methods. Both projects concluded after 2 or more years of postinjection research that the injected $\mathrm{CO}_{2}$ mineralized, a first to be demonstrated in the field (Matter and others, 2016; McGrail and others, 2017). Summaries of the results of these two projects, as well as discussions of past and potential injection projects, are provided in the following sections. It should be noted that the laboratory-based carbon dioxide mineralization research described in section 2 forms the foundation on which the pilot projects are based and is the source of the new technologies that developing projects may implement.

\subsection{CarbFix and SulFix Projects, Iceland}

$\mathrm{CO}_{2}$ and combined $\mathrm{CO}_{2}$-hydrogen sulfide $\left(\mathrm{H}_{2} \mathrm{~S}\right)$ gas-injection pilot projects at the Hellisheiði geothermal powerplant in Iceland have tested two injection systems named CarbFix and SulFix at neighboring sites. CarbFix mixes water with pure $\mathrm{CO}_{2}$ or $\mathrm{CO}_{2}$ and $\mathrm{H}_{2} \mathrm{~S}$ at depth within the injection well, and SulFix mixes the gases with water at the surface before injection. The gas dissolution common to both systems limits buoyancy and the potential for leakage along fractures.

CarbFix 1, phase 1 injected 175 t of pure $\mathrm{CO}_{2}$ during January through March 2012 (Matter and others, 2016). The $\mathrm{CO}_{2}$-water mixture was injected at a depth of about 500 meters (m) in the 2,000-m-deep injection well. The basalt storage reservoir lithology is present between depths of 400 and $800 \mathrm{~m}$. Low-permeability hyaloclastites above the storage formation act as a sealing unit because of their low vertical permeability (Aradóttir and others, 2015). There are eight monitoring wells between 150 and 1,300 $\mathrm{m}$ in depth (Matter and others, 2016). CarbFix 1, phase 2 injected 73 tons of a $\mathrm{CO}_{2}-\mathrm{H}_{2} \mathrm{~S}$ mixture, of which 55 tons were $\mathrm{CO}_{2}$, from June through August 2012 at the same location.

SulFix 1 was similar to CarbFix except that the gas mixture was dissolved into the water at the surface and the amount of water used was greater. Concentrations of the gases in the water were between 350 and 550 parts per million (ppm) for $\mathrm{CO}_{2}$ and 200 and 300 ppm for $\mathrm{H}_{2} \mathrm{~S}$ compared to concentrations of $26,000 \mathrm{ppm}$ and 6,800 ppm, respectively, for CarbFix 1, phase 2 (Aradóttir and others, 2015). 
Isotopic and nonreactive but volatile chemical tracers were used to track the movement of dissolved gases in these pilot projects. After 2 years, the observed dissolved inorganic carbon and carbon-14 isotope spike concentrations were much lower than what would be expected for simple mixing between injected $\mathrm{CO}_{2}$ and ambient groundwater (Matter and others, 2016). These results suggest that the precipitation of carbonates along the flow path accounted for more than 95 percent of the injected $\mathrm{CO}_{2}$. The presumed carbonate mineralization was corroborated by significant amounts of carbonate precipitation on a submerged pump that was recovered from a monitoring well. The reaction times appear to have been rapid. A larger industrial-scale injection project called CarbFix 2 began at the SulFix site in 2014. The results are not yet published in peer-reviewed journals.

\subsection{Wallula Basalt Pilot Project, Washington}

The Wallula basalt pilot project began in 2009 with the drilling of an injection well and extensive characterization of the Grande Ronde Basalt of the Columbia River Basalt Group in southeastern Washington State. A summary of the current results of the project noted that a 59-m-thick interval between depths of 828 and $887 \mathrm{~m}$ was selected for injection (McGrail and others, 2017). The potential reservoirs within the interval include three porous, low-density basalt flow tops. The upper two reservoirs are in the Indian Ridge member, and the lower reservoir is in the Ortley member of the Grande Ronde Basalt. The sealing units are interflows with low permeability and high density, and they serve as flow barriers to the buoyant $\mathrm{CO}_{2}$. A total of 1,000 t of supercritical $\mathrm{CO}_{2}$ was injected into the porous units over a 3-week period ending in August 2013. A daily limit of $40 \mathrm{t}$ was established to keep the pressure within 30 percent of the hydrostatic reservoir pressure (McGrail and others, 2017). Comparison of preinjection reservoir rock and waters with 2-year postinjection samples indicated that a new carbonate mineral phase formed in the pore space of the reservoir as a result of the injected $\mathrm{CO}_{2}$ rather than the dissolution and precipitation of preexisting carbonates.

Pore-water chemistry data indicated increases in total dissolved solids with major cation concentrations over initial baseline data. Fifty postinjection sidewall cores were taken in 2015 to investigate potential mineralization. Globular deposits of ankerite (a carbonate mineral in the dolomite group) were found in vugs and vesicles in an unknown number of those cores. Such deposits were not present in preinjection well cuttings or sidewall cores taken in 2009. Trends in $\mathrm{Ca}$ and $\mathrm{Fe}$ cation concentrations in the vugs showed higher $\mathrm{Ca}$ in the cores and increasing Fe moving outward, indicating dissolution of primary minerals and glass in the reservoir. Stable isotope data from the ankerite nodules were similar to those from the source $\mathrm{CO}_{2}$ and postinjection formation water but differed from calcite veins and other carbonates found during preinjection rock characterization (McGrail and others, 2017).

\subsection{Other Pilot Injection Projects}

In addition to the two injection projects discussed above, some smaller-scale field experiments have been completed, and researchers have plans for large-scale injection of $\mathrm{CO}_{2}$ into mafic rocks. To evaluate the dissolution rate of $\mathrm{Ca}$ and $\mathrm{Mg}$ silicates, Matter and others (2007) injected 1,400 liters of $\mathrm{CO}_{2-}$ saturated acidic water at a depth of $230 \mathrm{~m}$ into an 8-m-thick dolerite and sedimentary rock boundary layer at the bottom of the Palisades Diabase sill in New York. The Palisades Diabase sill is a thick sequence of Jurassic basalts intruded into the Triassic sedimentary sequence of the Newark Supergroup in the Mesozoic Newark basin. The acid was neutralized within hours, and the release rates of $\mathrm{Ca}^{2+}$ and $\mathrm{Mg}^{2+}$ available for mineralization were comparable to laboratory experiments.

A project funded by the U.S. Department of Energy to investigate the potential for $\mathrm{CO}_{2}$ mineralization in oceanic basalts in the Cascadia basin, offshore Washington and British Columbia, may provide insight into offshore $\mathrm{CO}_{2}$ injection and mineralization. At actively rifting (seismic) oceanic ridges, basalt is generated by sea-floor spreading and is highly fractured and permeable (Goldberg and Slagle, 2009) and therefore is a potential reservoir for injected $\mathrm{CO}_{2}$. Older basalts farther from spreading ridges lose porosity because of chemical weathering. The cited goal of the project is to complete an "integrated pre-feasibility study to characterize an ocean basalt reservoir for safe and permanent storage of 50 MMT [million metric tons] of $\mathrm{CO}_{2}{ }^{\prime \prime}$ (Goldberg, 2017, slide 3). The subsediment sea floor is composed of basaltic rock, and its use as a stable reservoir for $\mathrm{CO}_{2}$ sequestration would be a significant development if proven feasible, successful, and economically viable.

\section{Possible Environmental Effects}

The most conspicuous advantage of carbonate mineralization is the stable sequestration of $\mathrm{CO}_{2}$ gas. McCafferty and others (2016) noted that in general and compared to other methods of storage, the formation of stable minerals such as magnesite, dolomite, and calcite to store $\mathrm{CO}_{2}$ gas does not have certain legacy issues like acid mine drainage and would require significantly less long-term monitoring. However, no industrial process is without potential hazards, and some potential environmental concerns have been raised, described below. 
Induced seismicity is a potential hazard whenever fluids are injected into the subsurface (Zoback and Gorelick, 2012). Pressure-management techniques will be needed for subsurface $\mathrm{CO}_{2}$ mineralization. This potential hazard is mostly dependent on the likelihood of the interaction between the pressure perturbation caused by $\mathrm{CO}_{2}$ injection and existing faults. The injected $\mathrm{CO}_{2}$ could also react with the minerals present in faults to alter the friction and permeability properties (White and Foxall, 2016). Site characterization within the expected areal extent of the $\mathrm{CO}_{2}$ plume may identify faults near the injection well that should be avoided (Birkholzer and others, 2015).

Reports of induced seismicity directly associated with $\mathrm{CO}_{2}$ injection have been limited to a few instances of measurable microseismicity and very few felt seismic events (Gan and Frohlich, 2013; White and Foxall, 2016). The largest induced seismic events (estimated moment magnitude greater than M3) have been documented in cases of wastewater injection into deep sedimentary formations when the injections were in the basement or lowermost sediments (Ellsworth, 2013; Keranen and others, 2014; McGarr and others, 2015). The depth of $\mathrm{CO}_{2}$ injection, the proximity to the basement, and the potential for the resulting pressure front to invade deeper units are all relevant factors for $\mathrm{CO}_{2}$ storage project operators to consider (White and Foxall, 2016).

Lisabeth and others (2017) suggested that the precipitation of certain minerals along fault surfaces may affect frictional behavior and the likelihood of induced seismicity. The authors also suggested that the mineral dissolution from reaction with injected $\mathrm{CO}_{2}$ could concentrate stress and cause microcracking, which could maintain or increase the permeability of the rock. Although the microcracking could improve storage through permeability enhancement, it could also result in induced seismicity.

Injection of $\mathrm{CO}_{2}$ into basalts has been accomplished only at the pilot project scale, but the limitations imposed on the $\mathrm{CO}_{2}$ injection rate at the Wallula basalt pilot project closely approximate the pressure limitations typically assumed as necessary to model pressure-limited $\mathrm{CO}_{2}$ storage capacity in sedimentary formations (Birkholzer and others, 2015; Jahediesfanjani and others, 2017). Some lessons may be gleaned from the geothermal industry. In a survey of the induced seismic responses to fluid injection in geothermal and $\mathrm{CO}_{2}$ storage reservoirs, Evans and others (2012) found that fluid injection in geothermal wells in Iceland generally took place at very low pressure (or were even gravity driven) because the basalt reservoirs tended to have high natural transmissivity. High transmissivity generally promotes deep penetration of the pressure front generated by the fluid injection, which could increase the risk of induced seismicity. The authors also reported that these Icelandic basalt reservoirs were shallow, and the deepest injection well surveyed was $2.8 \mathrm{~km}$ deep. Despite the shallow depth of injection and low injection pressure, seismic responses to fluid injection were documented at four geothermal project sites. It is uncertain how analogous the fluid injection for these geothermal projects is to the injection of $\mathrm{CO}_{2}$ into basalts for the purpose of in situ storage via mineralization.

Aside from induced seismicity, other potential effects of $\mathrm{CO}_{2}$ mineralization are currently under investigation. Guyot and others (2011) noted that disposal of $\mathrm{CO}_{2}$ in the subsurface may change the behavior of microorganisms at depth and may lead to increased production of methane and $\mathrm{H}_{2} \mathrm{~S}$ gases. The authors noted that these outcomes are not known results of injection but rather areas where the science could be improved through experiments in natural $\mathrm{CO}_{2}$ accumulations, $\mathrm{CO}_{2-}$ enhanced hydrocarbon production fields, and injection pilot projects.

In a review of the potential reaction-based pitfalls of industrial $\mathrm{CO}_{2}$ mineralization, Haywood and others (2001), following methods from Newall and others (2000), documented the input requirements and byproducts generated by six ex situ mineral carbonation procedures. Aside from the energy and therefore financial cost required by many of the candidate procedures, environmental concerns such as large water requirements and the production of potentially harmful byproducts such as hydrochloric acid were noted. Ex situ $\mathrm{CO}_{2}$ mineralization also may have drawbacks related to surface impacts. These include increased noise and traffic, as well as visibility of the mining operations.

As noted in the CarbFix injection project in Iceland and other locations, $\mathrm{H}_{2} \mathrm{~S}$ gas may be associated with industrial $\mathrm{CO}_{2}$. Separating $\mathrm{H}_{2} \mathrm{~S}$ from the $\mathrm{CO}_{2}$ waste stream before injection is an additional cost burden that can be remedied through the co-injection of the gases. Schaef and others (2010) found that co-injecting $\mathrm{CO}_{2}$ and $\mathrm{H}_{2} \mathrm{~S}$ in basalts resulted in combined carbon and sulfur mineralization, forming carbonate minerals plus pyrite and (or) sulfate minerals. When subjected to oxidative alteration, pyrite weathering can form acidic waters. Schaef and others (2010) noted that although the pyrite began to inhibit carbonate formation as it grew on reaction surfaces, the carbonates eventually formed, and sulfur was incorporated in sulfate minerals.

\section{Economic Constraints and Risk}

The often-cited Intergovernmental Panel on Climate Change (2005) range of estimated costs for buoyant and residual saline storage $\left(\$ 0.5-\$ 8\right.$ per $\mathrm{t}$ of stored $\left.\mathrm{CO}_{2}\right)$ is commonly compared with the estimated costs of in situ $\mathrm{CO}_{2}$ mineralization $\left(\$ 50-\$ 100\right.$ per $\mathrm{t}$ of stored $\mathrm{CO}_{2}$ ) (Intergovernmental Panel on Climate Change, 2005; 2007). The economic value of the benefits of carbon mineralization's long-term stability and lower leakage risks, costs of monitoring, and costs of long-term liability coverage are suggested as possible reasons why in situ mineralization could be preferred to storage in saline aquifers. However, the benefits of carbon mineralization are not well quantified, and economic comparisons based solely on estimated costs, without considering the relative risks, clearly favor storage in saline aquifers. 
Given the lack of valuation estimates for in situ mineralization's stability benefits, it is useful to compare the costs of in situ mineralization with the costs of lower-risk saline storage. Zoback and Gorelick (2012) and others (Birkholzer and others, 2015; White and Foxall, 2016; Anderson, 2017b) have suggested that pressure buildup is a major source of potential risk associated with $\mathrm{CO}_{2}$ injection into saline aquifers. Therefore, cost estimates for pressure-limited storage could be more appropriate for comparison with the estimated costs of $\mathrm{CO}_{2}$ storage via in situ mineralization. Unfortunately, even recent studies do not account for the costs of the pressure management that will likely be necessary for storage in saline aquifers (Rubin and others, 2015; Anderson, 2017a).

Dynamic storage capacity can be defined as the maximum volume or tonnage of $\mathrm{CO}_{2}$ that can be injected (stored) per year (Gorecki and others, 2014). On the basis of the results of saline storage-reservoir simulations, Jahediesfanjani and others (2017) reported estimates of pressure-limited dynamic storage capacity for a case study of saline storage (without brine extraction) in the Mount Simon Sandstone in the Illinois basin, and Anderson and Jahediesfanjani (2017) listed estimates of the potential costs of pressure-limited storage for the case study. Representative capacity and cost estimates from this ongoing work are listed in table 2 for comparison with the costs of $\mathrm{CO}_{2}$ storage via in situ mineralization. In addition, the costs of brine extraction estimated by Harto and Veil (2011) have been added to the estimated costs of sedimentary reservoir storage without brine extraction (Morgan and Grant, 2014), and the estimated costs are listed in table 2. Harto and Veil (2011) assumed extraction of brines at a ratio of 1:1 per volume of $\mathrm{CO}_{2}$ injected, which could nullify pressure buildup, minimize associated risk, and make the entire volumetric storage capacity accessible to $\mathrm{CO}_{2}$. The dynamic capacity is greatest for storage in saline reservoirs with brine extraction (table 2; sections 1 and 2). When brine extraction or other pressure-management techniques, such as reducing injection rates, are not considered, the cost is seemingly low. However, when the costs of pressure management are considered, the estimated costs for saline storage are comparable to $\mathrm{CO}_{2}$ mineralization (table 2).

The significant economic advantages of $\mathrm{CO}_{2}$ storage via ex situ mineralization over the other storage options in table 2 are mostly due to the location of storage operations being on (or very near) the surface. These advantages include an absence of costs for injecting $\mathrm{CO}_{2}$ underground, zero expected reservoir pressure buildup or underground migration of $\mathrm{CO}_{2}$, low costs to recover marketable mineral carbonate commodities produced as a result of mineralization, and less dependence on the spatial location of geologic deposits of reactive material. The main constraint on the dynamic capacity of $\mathrm{CO}_{2}$ storage via ex situ mineralization is the availability of reactive material near stationary sources of $\mathrm{CO}_{2}$ on the surface. However, $\mathrm{CO}_{2}$ reacts with a wide variety of industrial waste materials and can contribute to the remediation of such wastes. The potential for remediation of wastes suggests environmental and economic benefits of ex situ mineralization in addition to the potential economic, environmental, and social benefits (such as the potential mitigation of $\mathrm{CO}_{2}$ concentrations in the atmosphere) that are common across all storage options listed in table 2 . There are also drawbacks such as visible activity at the surface and environmental effects from the operation of a plant.

Carbon mineralization is receiving increased interest as an option to complement saline $\mathrm{CO}_{2}$ storage. Interpreting the evidence in table 2 as suggesting that in situ carbon mineralization could be cost-comparable with other storage options is not to argue that any of these $\mathrm{CO}_{2}$ storage options is economically feasible. Still, the information in table 2 might be helpful to those responsible for determining the economic incentives that could be necessary to encourage greater deployment of the various $\mathrm{CO}_{2}$ storage options. Specifically, table 2 presents a comparison of the dynamic storage capacity, costs, relative benefits, and potential risks of some $\mathrm{CO}_{2}$ storage options. Table 2 includes recent estimates of the potential costs of pressure-limited sedimentary reservoir storage, which could be more appropriate for comparison with the costs of in situ $\mathrm{CO}_{2}$ mineralization than the estimated costs of sedimentary reservoir storage that do not include the costs of pressure management required to mitigate risk. According to the comparisons in table 2 , in situ carbon mineralization could be a more cost-competitive $\mathrm{CO}_{2}$ storage option than has been suggested by other comparisons (such as Olajire, 2013).

\section{Regional Carbon Dioxide Mineralization Feasibility in the United States}

Abundant resources for $\mathrm{CO}_{2}$ mineralization are present in the United States in the form of in situ mafic and ultramafic rocks, as well as mine wastes derived from them. Whether the use of these resources is technically or economically feasible, however, is a function of multiple variables, including the size of the target rock body or mine tailings pile, composition and reaction rates of relevant minerals, the permeability and porosity of the material, the availability of $\mathrm{CO}_{2}$, environmental risks, and mitigation costs. In this section, we take a regional approach to describe the pros and cons of $\mathrm{CO}_{2}$ mineralization in different regions of the United States and address potential storage sites. Figure 1 is a map of mafic and ultramafic rock resources in the United States that could be potential sinks for $\mathrm{CO}_{2}$ mineralization. To generate figure 1 and the regional maps referenced in this section, geologic data were compiled and, in some instances, simplified from the following sources: Lambert and others (1988), Ojakangas and others (2001), Reed and others (2005), Sherrod and others (2007), Garrity and Soller (2009), Krevor and others (2009), and Barry and others (2013). The baseline requirement for rock types suitable for $\mathrm{CO}_{2}$ mineralization is a high concentration of $\mathrm{Mg}^{2+}, \mathrm{Ca}^{2+}$, 
Table 2. Summary of potential costs, benefits, and risks for carbon dioxide mineralization and saline storage methods.

[t, metric ton; $\mathrm{CO}_{2}$, carbon dioxide; yr, year; $\mathrm{km}$, kilometer; $\mathrm{m}^{3}$, cubic meter; $\mathrm{CaO}$, calcium oxide; $\mathrm{MgO}$, magnesium oxide]

\begin{tabular}{|c|c|c|}
\hline Dynamic capacity & Costs (in U.S. dollars) & Benefits and risks \\
\hline \multicolumn{3}{|c|}{ 1. Sedimentary reservoir storage assuming no pressure limitations or associated risks } \\
\hline About $1,070,000 \mathrm{t} \mathrm{CO}_{2} / \mathrm{yr} /$ injection well ${ }^{1}$ & - $\$ 7$ to $\$ 13 / \mathrm{tCO}_{2}$ (or less). ${ }^{1,2}$ & $\begin{array}{l}\text { - Lowest apparent cost because estimates do not } \\
\text { include management of pressure, water, or risk. } \\
\text { - Dynamic capacity is equal to technically feasible } \\
\text { capacity. } \\
\text { - Storage capacity is widely distributed (reservoirs } \\
\text { may exist within } 80 \mathrm{~km} \text { of more than } 70 \text { percent } \\
\text { of the major stationary } \mathrm{CO}_{2} \text { emitters in the } \\
\text { United States [Dahowski and others, 2005]). }\end{array}$ \\
\hline \multicolumn{3}{|c|}{ 2. Sedimentary reservoir storage with pressure management (either by reducing injection rates or brine extraction) } \\
\hline $\begin{array}{l}\text { About } 300,000 \text { to } 1,070,000 \text { t } \mathrm{CO}_{2} / \mathrm{yr} / \\
\text { injection well }{ }^{1,3}\end{array}$ & - $\$ 20$ to $\$ 80 / \mathrm{t} \mathrm{CO}_{2}$ (or more). ${ }^{3,4}$ & $\begin{array}{l}\text { - Lower risk (but higher cost) than non-pressure- } \\
\text { limited estimates. } \\
\text { - Pressure-limited dynamic capacity without brine } \\
\text { extraction could be significantly greater than } \\
\text { for mineralization, and with brine extraction } \\
\text { it could approach technically feasible storage } \\
\text { capacity. } \\
\text { - Storage capacity is widely distributed (reservoirs } \\
\text { may exist within } 80 \mathrm{~km} \text { of more than } 70 \text { percent } \\
\text { of the major stationary } \mathrm{CO}_{2} \text { emitters in the } \\
\text { United States [Dahowski and others, 2005]). }\end{array}$ \\
\hline
\end{tabular}

3.a. In situ $\mathrm{CO}_{2}$ mineralization in basaltic rocks

About 14,600 t CO$_{2} /$ yr/injection well ${ }^{6} \quad \bullet \$ 50$ to $\$ 100 / \mathrm{CO}_{2}$ (Intergovernmental

Panel on Climate Change, 2005, 2007).

- $\$ 54 / \mathrm{t} \mathrm{CO}_{2}$ (Olajire, 2013).

- $\$ 30 / \mathrm{t} \mathrm{CO}_{2}{ }^{7}$ (Zalzal, 2017).
- Lower leakage risk than saline storage options and may not require decades-long postinjection monitoring.

- Pressure management is necessary to control for the risk of induced seismicity.

- Lower dynamic capacity and not as widely distributed (not as close to as many $\mathrm{CO}_{2}$ sources) as saline storage options.

3.b. In situ $\mathrm{CO}_{2}$ mineralization in ultramafic rocks

Offshore: 1,000 t $\mathrm{CO}_{2} / \mathrm{yr} /$ injection well

Onshore: $1 \mathrm{t} \mathrm{CO}_{2} / \mathrm{yr} / \mathrm{m}^{3}$ in olivine-hosted aquifers $^{8}$
- Storage cost data are not available.

- As a proxy, a dated Intergovernmental Panel on Climate Change (2005) estimate of $\$ 0.50$ to $\$ 8 / \mathrm{t} \mathrm{CO}_{2}$ for injection into deep saline-filled formations is used (for example, Power and others, 2014).
- Injection into ultramafic rocks could pose a significant risk of induced seismicity.

- Pressure-management costs are not included in cost estimates.

- Dynamic storage capacity in onshore ultramafic rocks could be orders of magnitude less than that in basalts (but data are lacking).

\begin{tabular}{|c|c|c|}
\hline \multicolumn{3}{|c|}{ 4. Ex situ $\mathrm{CO}_{2}$ mineralization } \\
\hline $7,000,000 \mathrm{t} \mathrm{CO}_{2} / \mathrm{yr}^{7}$ & $\begin{array}{l}\text { - } \$ 8 / \mathrm{t} \mathrm{CO}_{2} \text { stored in } \mathrm{CaO} \text { - and } \mathrm{MgO} \text {-rich } \\
\text { industrial wastes or ultramafic mine } \\
\text { tailings (Power and others } 2014 \text { ). The } \\
\text { estimated cost is the same for } \mathrm{CO}_{2} \text { stored } \\
\text { in steel slag. }{ }^{9} \\
\text { - } \$ 54 / \mathrm{t}_{2} \text { for mined material already at } \\
\text { the surface (Olajire, 2013). } \\
\text { - } \$ 100 / \mathrm{t} \mathrm{CO}_{2} \text { (or more) associated with } \\
\text { mining and processing of feedstock, } \\
\text { additional processing at the surface, and } \\
\text { the energy required for each processing } \\
\text { stage (Power and others, 2013). }\end{array}$ & $\begin{array}{l}\text { - No risky pressure buildup because there are no } \\
\text { underground injections. } \\
\text { - Economically feasible only at the local scale. } \\
\text { - Can provide environmental benefits such as } \\
\text { mitigating the effects of alternative treatments, } \\
\text { emissions, or disposal of industrial wastes. } \\
\text { - Environmental concerns include surface impacts } \\
\text { of mining operations. } \\
\text { - Costs of storage can be offset by sales of mineral } \\
\text { carbonates that are produced because these } \\
\text { products will be available at the surface. }\end{array}$ \\
\hline
\end{tabular}


Table 2. Summary of potential costs, benefits, and risks for carbon dioxide mineralization and saline storage methods. —Continued [t, metric ton; $\mathrm{CO}_{2}$, carbon dioxide; yr, year; $\mathrm{km}$, kilometer; $\mathrm{m}^{3}$, cubic meter; $\mathrm{CaO}$, calcium oxide; $\mathrm{MgO}$, magnesium oxide]

\footnotetext{
'Based on baseline results from the National Energy Technology Laboratory's Saline Storage Cost Model (Morgan and Grant, 2014).

${ }^{2}$ For storage onshore in the United States in 2013 U.S. dollars (Rubin and others, 2015).

${ }^{3}$ Based on preliminary results of simulations of pressure-limited $\mathrm{CO}_{2}$ storage capacity and costs for the Mount Simon Sandstone (Anderson and Jahediesfanjani, 2017; Jahediesfanjani and others, 2017).

${ }^{4}$ Brine extraction costs based on Harto and Veil (2011), who assumed extraction of brines at a ratio of 1:1 per volume of $\mathrm{CO}_{2}$ injected.

${ }^{5}$ Gorecki and others (2014, p. 8).

${ }^{6}$ Based on 3 weeks of injection at the Wallula basalt pilot project, where the rate of injection was controlled to maintain pressure within 30 percent of hydrostatic conditions (McGrail and others, 2017).

${ }^{7}$ Based on injection of $\mathrm{CO}_{2}$ and hydrogen sulfide mixed with water into basalts in Iceland. The injection rate was not pressure limited (Zalzal, 2017).

${ }^{8}$ Data were not available for the maximum rate of injection of $\mathrm{CO}_{2}$ into ultramafic-hosted aquifers per well. The estimated injection rate per cubic meter of aquifer volume is from Power and others (2013).

${ }^{9} \mathrm{Based}$ on the average availability per year of fly ash, cement kiln dust, and iron and steel slag in close proximity to stationary sources of $\mathrm{CO}_{2}$ emissions in the United States (Kirchofer and others, 2013).
}

or $\mathrm{Fe}^{2+}$ cations, which are required for the reactions to form $\mathrm{Mg}, \mathrm{Ca}$, or $\mathrm{Fe}$ carbonates. In the regional maps, point sources of $\mathrm{CO}_{2}$ from various industrial sectors are shown within a 100-mile (160-kilometer [km]) buffer of potential mafic and ultramafic reservoirs. The 100 -mile buffer is representative of a distance in which long distance pipelines would not be needed to transport $\mathrm{CO}_{2}$ (Dahowski and others, 2005).

Use of the terms "surface mafic rocks" and "surface ultramafic rocks" comes with the understanding that these rocks actually may be concealed at the ground surface by soil and surficial sediments like alluvium, or by unconsolidated glacial sediments which in some places are hundreds of feet thick.

\subsection{Pacific Northwest}

The Columbia River basin contains 53,700 cubic miles (223,832 cubic kilometers) of reactive flood basalt (Reidel and others, 2002) (fig. 2A) and is estimated to be able to store between 10 and $100 \mathrm{Gt} \mathrm{CO}_{2}$ (McGrail and others, 2006; Gislason and others, 2010). The kinetics of $\mathrm{CO}_{2}$ mineralization for basalts are well studied (examples include Gislason and others, 2010; Schaef and others, 2010; Rosenbauer and others, 2012). The results of a recent pilot project involving the injection of $1,000 \mathrm{t}$ of $\mathrm{CO}_{2}$ in the Columbia River basin indicated that carbonate mineralization was complete in 2 years (McGrail and others, 2017). A similar study of $\mathrm{CO}_{2}$ injection in Icelandic basalts showed greater than 95 percent mineralization in less than 2 years (Matter and others, 2016). Because of the high porosity and permeability, there is low risk of reaching fracture pressures in the basalt that could lead to induced seismicity and leakage. Compared to other parts of the country, the Pacific Northwest has fewer stationary sources of $\mathrm{CO}_{2}$ (fig. $2 \mathrm{~A}$ ) (most of which are related to electric power generation and agricultural processing), lower $\mathrm{CO}_{2}$ emissions, and less infrastructure for well injection (National Energy Technology Laboratory, 2015).

Large expanses of ultramafic rocks are present in Washington and Oregon, and ultramafic complexes also occur in southwestern Montana. The ultramafic rocks of Washington and Oregon are ophiolite complexes, sections of oceanic plates (crust and uppermost mantle) that have been accreted to and thrust over portions of the western margin of the North American plate through convergent tectonic collisions. Krevor and others (2009) noted that northwest Washington's Ingalls Tectonic Complex and neighboring bodies are dominantly dunite and harzburgite, whereas the Twin Sisters Dunite contains large volumes of unaltered olivine (fig. $2 A$ ). The latter would be a good target for mineralization because of its greater potential reactivity and inherent permeability. The Twin Sisters Dunite also hosts an active olivine mine and therefore is a potential source of mining waste for ex situ mineralization. The Josephine Peridotite and Canyon Mountain Complex in Oregon (fig. 2A) are also regional ultramafic bodies that could potentially host mineralization operations, though they are not near any significant point sources of $\mathrm{CO}_{2}$.

The Stillwater igneous complex in southwestern Montana (fig. $2 A$ ) is a mined, layered intrusive deposit that is the only U.S. producer of platinum-group elements. A peridotite layer in the ultramafic zone of the intrusion is composed mostly of olivine and some pyroxene minerals that are $20-80$ percent serpentinized (Page, 1976). The ultramafic zone of the intrusion is only minimally mined, which precludes using tailings or processed materials for ex situ mineral carbonation. The region around the Stillwater platinum-palladium mine in the Stillwater igneous complex has some $\mathrm{CO}_{2}$ sources, but it may be more economically feasible to capture the emissions from the mine's onsite ore-refining operations. 


\subsection{California}

California contains abundant ultramafic rocks for $\mathrm{CO}_{2}$ storage within multiple ophiolite and pluton assemblages (Krevor and others, 2009). The Trinity peridotite in the eastern Klamath Mountains of northern California (fig. 2B) crops out in approximately half the area of a region roughly 50 km x 75 km (Quick, 1981; Irwin, 2003). Seismic data indicate these rocks extend as far east as Mount Shasta in the subsurface (Fuis and others, 1987). The Trinity peridotite is one of the largest in the United States. Point sources of industrial and agricultural $\mathrm{CO}_{2}$ are small in this area, and they are mostly limited to the regions around Redding, California, and Klamath Falls, Oregon (fig. 2B).

The Central Valley of California contains numerous industrial, agricultural, and electric power generation point sources of $\mathrm{CO}_{2}$ emissions. Ultramafic rocks in close proximity surround the entire Central Valley (fig. 2B). These rocks could potentially serve as stable storage reservoirs for the emissions from these industrial sectors. The potential to activate known or unknown faults is a risk that must be taken into account for any $\mathrm{CO}_{2}$ injection project, especially those in the seismically active regions of the Western United States.

The chrysotile asbestos mines of the Coalinga mining district in California (fig. 2B) operated from 1917 to 2002 and were the last mines in the United States devoted to asbestos production. The remaining mine waste and the surrounding ultramafic complex may be suitable targets for $\mathrm{CO}_{2}$ mineralization of chrysotile asbestos. The locations of the individual asbestos mines in the district are provided in Van Gosen and Clinkenbeard (2011). The chrysotile asbestos exploited by these mines occurs within the New Idria serpentinite mass (fig. $2 B$ ), a serpentinized peridotite that crops out for approximately 117 square kilometers. The New Idria serpentinite mass contains a large number of serpentine-group minerals (Wise and Moller, 1995).

Large amounts of asbestos-bearing waste rock and serpentinite rock remain in the Coalinga district, and some of the mining areas have been designated as Superfund sites (U.S. Army Corps of Engineers, 2016). Carbonation of the tailings would have the added benefit of mitigating the potential asbestos exposures to recreational users of the Coalinga area. Preventing such exposures has been a challenge for land management and environmental protection agencies (Coleman, 1996; U.S. Environmental Protection Agency, 2008; U.S. Army Corps of Engineers, 2016).

Mafic lavas are present in northeastern California's Modoc Plateau (fig. 2B) and also in southern Oregon. These Miocene- through Quaternary-age volcanics occupy the transition zone between the Cascade Mountains to the west and Basin and Range Province to the east and underlie an area many times larger than the Trinity peridotite (Gay and Aune, 1958). Seismic studies of the plateau indicate layered flood basalts and associated sedimentary deposits are present to a depth of $3.5 \mathrm{~km}$ below sea level (Fuis and others, 1987). Like the nearby Trinity peridotite, there are few major sources of $\mathrm{CO}_{2}$ in the Modoc Plateau region.

Peridotite-hosted alkaline springs in California (Barnes and O'Neil, 1969) offer the possibility of producing $\mathrm{CaOH}-$ rich water to directly capture $\mathrm{CO}_{2}$ from air to form calcite. This process is an accelerated version of the natural process that forms travertine terraces in peridotites at the surface and carbonates in peridotites at depth (Cipolli and others, 2004).

\subsection{Hawaii}

Basalts in Hawaii, like the Columbia River basalts, represent a volumetrically large potential $\mathrm{CO}_{2}$ sink. Hawaii has significant volcanic stratigraphy with highly porous vesicular flow boundaries and high permeability within natural fractures. Compared to the potential pressure-management issues associated with low-porosity and -permeability ultramafic rocks, there is less risk of induced seismicity in these mafic basalts. Hawaii's history of major landslides (Moore and others, 1989), however, indicates that extensive, site-specific characterization efforts would be needed to avoid these risks. The naturally high heat flow in Hawaii may increase reaction rates. The kinetics of the reaction would be most similar to those reported by Matter and others (2016) for Iceland, another active volcanic setting with high heat flow, as a low-end estimate, because those proof-of-concept pilot injections were $\mathrm{CO}_{2}$ limited and not designed to maximize mineralization. Ongoing efforts in Iceland using faster rates of injection may provide more appropriate estimates of the potential mineralization rates in high-heat-flow basalts. Hawaii has low $\mathrm{CO}_{2}$ emissions, but there are local stationary sources of $\mathrm{CO}_{2}$, mostly from electric power generation (fig. 3). The State has less well and pipeline infrastructure to utilize (National Energy Technology Laboratory, 2015) but has considerable basalt resources for mineralization.

\subsection{Desert Southwest}

The Tertiary basalts of the Basin and Range Province in the desert Southwest (fig. $2 B$ ) are widespread over a highheat-flow extensional environment, but they are volumetrically minor compared to the Columbia River and Hawaiian basalts. Most of the rocks are volumetrically small, dispersed extrusive basalts in volcanic fields and likely have subsurface mafic dikes and sills. There is perhaps an increased leakage risk for injection of volatiles into regions with extensive preexisting volcanism and faulting. Well and pipeline infrastructure and stationary sources of $\mathrm{CO}_{2}$ are sparse here, although they increase toward southeastern New Mexico and western Texas where numerous oil and gas wells and $\mathrm{CO}_{2}$ infrastructure exist in the Permian basin. 


\subsection{Midcontinent}

The midcontinent region and upper Midwest contain abundant subsurface basalts, potentially as much as $20 \mathrm{~km}$ thick, within the Mesoproterozoic Midcontinent Rift (Cannon and others, 1989). This region includes surface exposures in Wisconsin, Michigan, and Minnesota, including the Duluth Complex, and subsurface plutonic basalts farther south in Wisconsin and Minnesota as well as in Michigan, Iowa, Nebraska, and Kansas (fig. 4). The subsurface Glen Mountains Layered Complex of early Paleozoic age is found even farther south in Oklahoma and Texas (Lambert and others, 1988). Not only are there large volumes of subsurface basalts in the midcontinent region, but they also fall in an area with abundant stationary sources of $\mathrm{CO}_{2}$ (fig. 4). The highest- $\mathrm{CO}_{2}$-output stationary sources include electric powerplants in northern Minnesota and along the Nebraska-Iowa border. Other sites include industrial sources of $\mathrm{CO}_{2}$ near the Duluth Complex of northern Minnesota and in Michigan and ethanol plants in Minnesota, Iowa, and Nebraska. The subsurface basalts in Oklahoma and Texas are much closer to regions of existing well infrastructure for petroleum and natural gas production. Unlike the highly porous, near-surface Hawaiian and Columbia River basalts, these deep basalts are likely to be significantly less porous and to have unknown amounts of previous carbonation. Induced seismicity from wastewater injection is a known hazard in this region (for example, see Ellsworth, 2013), particularly for fluids injected into basement rocks; therefore, injection pressures would need to be regulated. Because of the economic cost of accessing rocks at great depth, the significant volumes of mafic rocks below the shallow subsurface may not be viable storage options unless the economics of storage change significantly.

\subsection{Eastern States}

The Eastern States contain both basalt and ultramafic resources for $\mathrm{CO}_{2}$ storage. The Mesozoic rift basins in the Eastern United States are a source of igneous and metaigneous rift basalts that exist both in the subsurface and as surface exposures. These basalts are part of the CAMP, a large continental flood-basalt province that formed during rifting of the supercontinent Pangea (Goldberg and others, 2010). Like the subsurface Midcontinent Rift basalts, eastern Mesozoic rift basalts may be partially metamorphosed and may have low porosity and permeability. Point sources of $\mathrm{CO}_{2}$ are abundant here, particularly electric powerplants, cement plants, and other industrial sites. There is well infrastructure in the nearby Appalachian basin but little to none within the CAMP.

The Eastern States also have resources of ultramafic rocks in sparse outcrops from Georgia to Maine (fig. 1). These include the dunites of North Carolina, as well as peridotite and metamorphic serpentinites. The asbestos mines shown in figure 5 are derived from these ultramafic serpentinite outcrops. Dunites, peridotites, and serpentinites, though ultramafic and the most $\mathrm{CO}_{2}$-reactive of common natural materials, generally have very low porosity and permeability and therefore a small surface area of reaction. They also have highly variable mineralogies and degrees of natural carbonation, meaning that the amount of $\mathrm{CO}_{2}$ that can be stored is highly variable and dependent on the specific subtypes of ultramafic rock.

The Belvidere mine in northern Vermont is an example of a potential site for carbonate mineralization of asbestos with $\mathrm{CO}_{2}$. Until its closing in 1993, the Belvidere mine was a site of mining of veins of chrysotile asbestos developed within metasomatized dunite and serpentinite (Cady and others, 1963; Chidester and others, 1978; Van Baalen and others, 1999). The ultramafic body that forms Belvidere Mountain and hosts the chrysotile deposits is approximately $3,400 \mathrm{~m}$ (11,000 feet [ft]) long, $1,800 \mathrm{~m}(6,000 \mathrm{ft})$ wide, and as much as $450 \mathrm{~m}(1,500 \mathrm{ft})$ thick (Chidester and others, 1978). Large piles of waste rock of metasomatized dunite and serpentinite, some containing remnants of chrysotile, remain at the Belvidere mine site and the nearby processing plant (Krevor and others, 2009).

\section{Conclusions}

$\mathrm{CO}_{2}$ mineralization has the potential to provide a stable storage mechanism for anthropogenic or atmospheric $\mathrm{CO}_{2}$. Mineral carbonation requires sources of $\mathrm{Ca}^{2+}, \mathrm{Mg}^{2+}$, and (or) $\mathrm{Fe}^{2+}$ cations, such as mafic and ultramafic rocks, to react with the $\mathrm{CO}_{2}$. The United States contains abundant resources of mafic basalts and ultramafic rocks that could be used for mineral carbonation to capture and store $\mathrm{CO}_{2}$ through subsurface injection or surface reactions with industrial byproducts. Particularly suitable targets include asbestos or other ultramafic mine tailings, in situ ultramafic rocks on the East and West Coasts, the Columbia River Basalts in the Pacific Northwest, and the Midcontinent Rift zone basalts in the midcontinent because of their proximity to major sources of $\mathrm{CO}_{2}$. Though not a major emitter of $\mathrm{CO}_{2}$, Hawaii is endowed with significant volumes of potential reservoir rocks that could be utilized to mitigate local $\mathrm{CO}_{2}$ emissions.

$\mathrm{CO}_{2}$ storage by mineralization is achieved by the formation of stable, solid carbonate minerals that capture and lock up the $\mathrm{CO}_{2}$ in mineral form and thus do not pose the leakage risks seen with fluid injection methods. Additionally, the burden of long-term monitoring of a fluid plume of $\mathrm{CO}_{2}$ in the subsurface is significantly reduced. However, there are risks and potential environmental effects associated with $\mathrm{CO}_{2}$ mineralization technologies. Injection of $\mathrm{CO}_{2}$ into subsurface environments carries the risk of induced seismicity just as with any subsurface injection activity. Depending on the mineralogy and conditions, it is possible that there could be unwanted byproducts of the reaction. There also may be increases in noise and traffic in these settings and potentially large water requirements.

Cost, risk, and the availability of suitable rock are the main restrictions to the adoption of mineral carbonation 


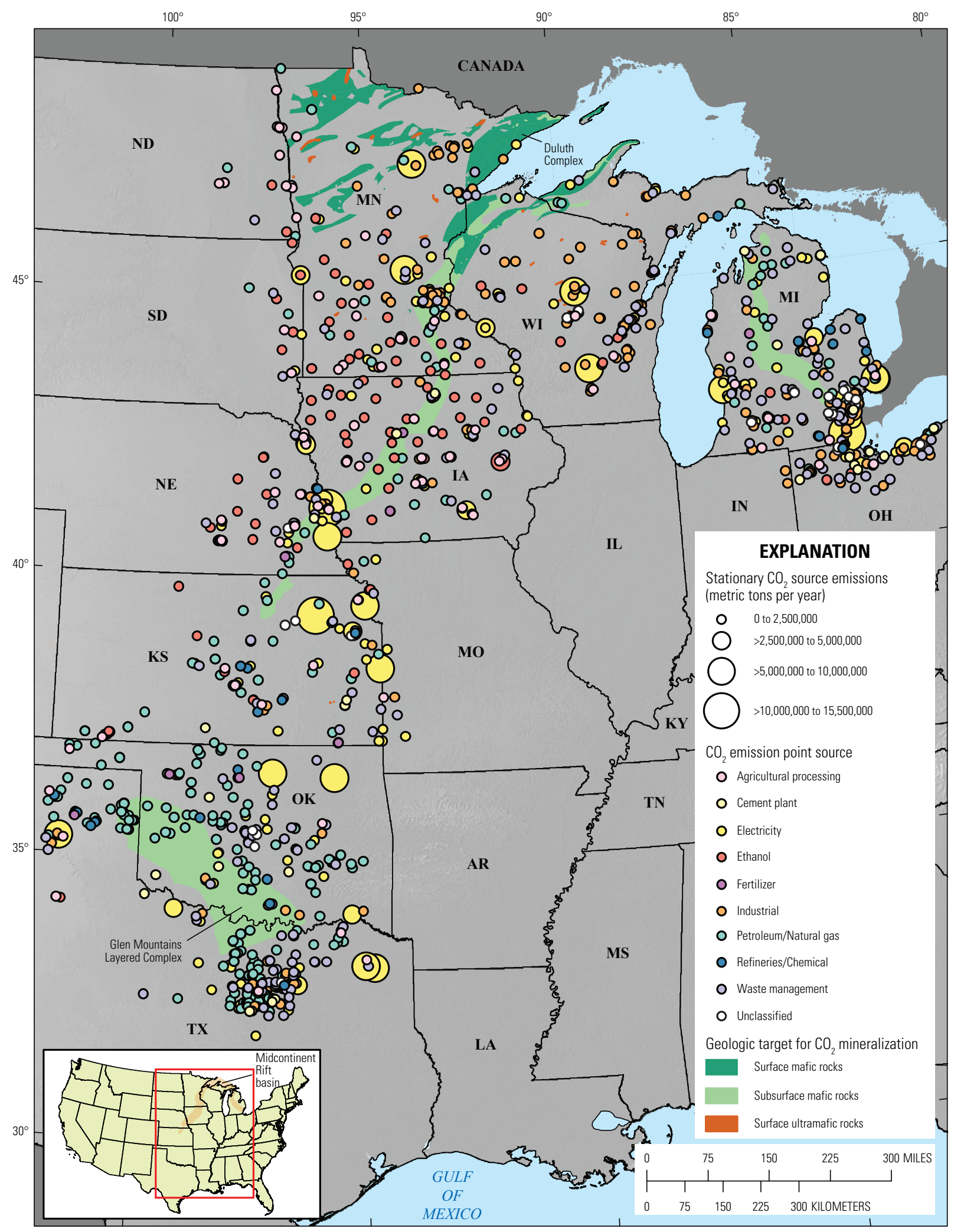

Figure 4. Map of stationary point sources of carbon dioxide $\left(\mathrm{CO}_{2}\right)$ emissions within 100 miles (160 kilometers) of mafic and ultramafic rocks in the midcontinent United States. Geologic data were compiled and, in some instances, simplified from Lambert and others (1988), 0jakangas and others (2001), Reed and others (2005), Garrity and Soller (2009), and Krevor and others (2009). Outlines of ultramafic-rock polygons were used to increase visibility. $\mathrm{CO}_{2}$ pointsource data are from National Energy Technology Laboratory Carbon Storage Atlas (2015). Base map was compiled from data from Environmental Systems Research Institute, Inc. (2007a,b) and Jarvis and others (2008). 


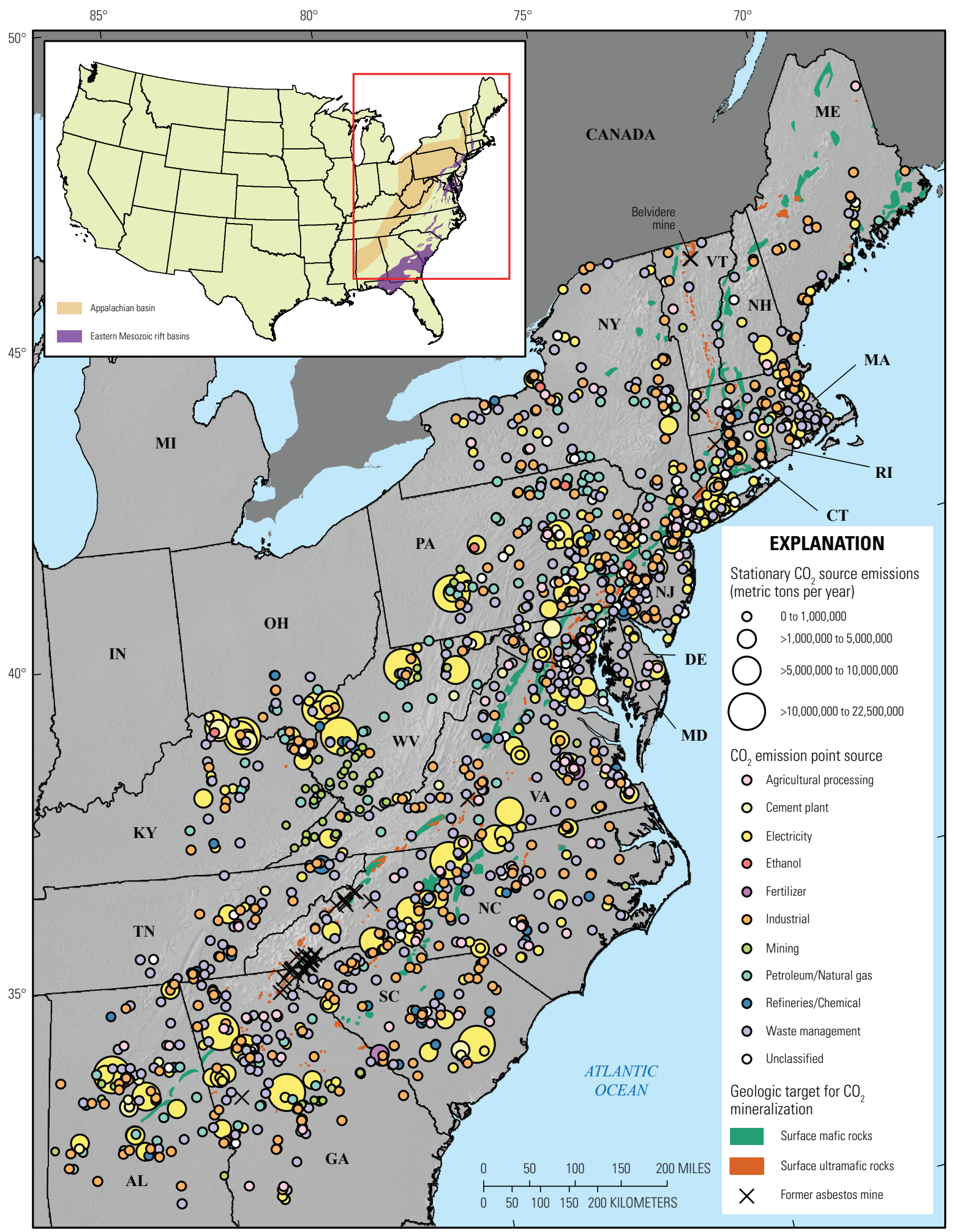

Figure 5. Map of stationary point sources of carbon dioxide $\left(\mathrm{CO}_{2}\right)$ emissions within 100 miles (160 kilometers) of mafic and ultramafic rocks in the Eastern United States. Geologic data were compiled and, in some instances, simplified from Reed and others (2005), Garrity and Soller (2009), and Krevor and others, (2009). Outlines of ultramafic-rock polygons were used to increase visibility. Asbestos mines were compiled from past producing mines described in Van Gosen $(2006 \mathrm{a}, \mathrm{b})$. $\mathrm{CO}_{2}$ point-source data are from National Energy Technology Laboratory Carbon Storage Atlas (2015). Base map was compiled from data from Environmental Systems Research Institute, Inc. $(2007 \mathrm{a}, \mathrm{b})$ and Jarvis and others (2008). 
processes, and these issues are active areas of research. The costs and benefits of $\mathrm{CO}_{2}$ mineralization are compared here to $\mathrm{CO}_{2}$ storage in saline reservoirs using estimates of pressure-limited dynamic storage capacity. Investigations based on kinetic experiments, as well as demonstration pilot projects, indicate that reaction rates for basalts and ultramafic rocks are much faster than initial projections suggested. Increased technological developments combined with larger pilot projects may help to decrease costs and establish carbon mineralization as a cost-effective $\mathrm{CO}_{2}$ sequestration method in the future.

\section{References Cited}

Anderson, S.T., 2017a, Cost implications of uncertainty in $\mathrm{CO}_{2}$ storage resource estimates-A review: Natural Resources Research, v. 26, no. 2, p. 137-159. [Also available at https:// doi.org/10.1007/s11053-016-9310-7.]

Anderson, S.T., 2017b, Risk, liability, and economic issues with long-term $\mathrm{CO}_{2}$ storage-A review: Natural Resources Research, v. 26, no. 1, p. 89-112. [Also available at https:// doi.org/10.1007/s11053-016-9303-6.]

Anderson, S.T., and Jahediesfanjani, H., 2017, Case studyDynamic pressure-limited capacity and costs of $\mathrm{CO}_{2}$ storage in the Mount Simon Sandstone [abs.], in U.S. Association for Energy Economics and International Association for Energy Economics North American Conference, 35th, Houston, Tex., November 12-15, 2017: Cleveland, Ohio, U.S. Association for Energy Economics, 2 p. [Also available at http://www.usaee.org/USAEE2017/ program_concurrent.aspx\#3.]

Aradóttir, E.S.P., Gunnarsson, I., Sigfússon, B., Gíslason, S.R., Oelkers, E.H., Stute, M., Matter, J.M., Snaebjörnsdottir, S.Ó., Mesfin, K.G., Alfredsson, H.A., Hall, J., Arnarsson, M. T., Dideriksen, K., Júliusson, B.M., Broecker, W.S., and Gunnlaugsson, E., 2015, Towards cleaner geothermal energy - Subsurface sequestration of sour gas emissions from geothermal power plants, in Proceedings of the World Geothermal Congress, Melbourne, Australia, April 19-25, 2015: Bochum, Germany, International Geothermal Association, 12 p. [Also available at https:/www.geothermal-energy.org/pdf/IGAstandard/ WGC/2015/14116.pdf.]

Barnes, I., and O’Neil, J.R., 1969, The relationship between fluids in some fresh Alpine-type ultramafics and possible modern serpentinization, Western United States: GSA Bulletin, v. 80, no. 10, p. 1947-1960. [Also available at https://doi.org/10.1130/0016-7606(1969)80[1947:TRBFIS] 2.0.CO;2.]
Barry, T.L., Kelley, S.P., Reidel, S.P., Camp, V.E., Self, S., Jarboe, N.A., Duncan, R.A., and Renne, P.R., 2013, Eruption chronology of the Columbia River Basalt Group, in Reidel, S.P., Camp, V.E., Ross, M.E., Wolff, J.A., Martin, B.S., Tolan, T.L., and Wells, R.E., eds., The Columbia River flood basalt province: Geological Society of America Special Paper 497, p. 45-66. [Also available at https://doi.org/10.1130/2013.2497(02).]

Béarat, H., McKelvy, M.J., Chizmeshya, A.V.G., Gormley, D., Nunez, R., Carpenter, R.W., Squires, K., and Wolf, G.H., 2006, Carbon sequestration via aqueous olivine mineral carbonation-Role of passivating layer formation: Environmental Science \& Technology, v. 40, no. 15, p. 4802-4808. [Also available at https://doi.org/10.1021/es0523340.]

Bédard, J.H., and Escayola, M., 2010, The Advocate ophiolite mantle, Baie Verte, Newfoundland-Regional correlations and evidence for metasomatism: Canadian Journal of Earth Sciences, v. 47, no. 3, p. 237-253. [Also available at https:// doi.org/10.1139/E10-004.]

Beinlich, A., Plümper, O., Hövelmann, J., Austrheim, H., and Jamtveit, B., 2012, Massive serpentinite carbonation at Linnajavri, N-Norway: Terra Nova, v. 24, no. 6, p. 446-455. [Also available at https://doi.org/10.1111/ j.1365-3121.2012.01083.x.]

Benson, S., Cook, P., Anderson, J., Bachu, S., Nimir, H.B., Basu, B., Bradshaw, J., Deguchi, G., Gale, J., von Goerne, G., Heidug, W., Holloway, S., Kamal, R., Keith, D., Lloyd, P., Rocha, P., Senior, B., Thomson, J., Torp, T., Wildenborg, T., Wilson, M., Zarlenga, F., and Zhou, D., 2005, Underground geological storage, chap. 5 of Intergovernmental Panel on Climate Change, IPCC special report on carbon dioxide capture and storage [Prepared by Working Group III of the IPCC]: New York, Cambridge University Press, p. 195-276. [Also available at https://www.ipcc.ch/pdf/ special-reports/srces/srccs_wholereport.pdf.]

Birkholzer, J.T., Oldenburg, C.M., and Zhou, Q., 2015, $\mathrm{CO}_{2}$ migration and pressure evolution in deep saline aquifers: International Journal of Greenhouse Gas Control, v. 40, p. 203-220. [Also available at https://doi.org/10.1016/ j.ijggc.2015.03.022.]

Bobicki, E.R., Liu, Q., Xu, Z., and Zeng, H., 2012, Carbon capture and storage using alkaline industrial wastes: Progress in Energy and Combustion Science, v. 38, no. 2, p. 302-320. [Also available at https://doi.org/10.1016/ j.pecs.2011.11.002.] 
Bruni, J., Canepa, M., Chiodini, G., Cioni, R., Cipolli, F., Longinelli, A., Marini, L., Ottonello, G., and Vetuschi Zuccolini, M., 2002, Irreversible water-rock mass transfer accompanying the generation of the neutral, $\mathrm{Mg}-\mathrm{HCO}_{3}$ and high-pH, $\mathrm{Ca}-\mathrm{OH}$ spring waters of the Genova province, Italy: Applied Geochemistry, v. 17, no. 4, p. 455-474. [Also available at https://doi.org/10.1016/S08832927(01)00113-5.]

Cady, W.M., Albee, A.L., and Chidester, A.H., 1963, Bedrock geology and asbestos deposits of the upper Missisquoi Valley and vicinity, Vermont, chap. B of Contributions to economic geology: U.S. Geological Survey Bulletin 1122, p. B1-B78, 1 pl. (scale 1:31:680), and 1 oversize table in pocket. [Also available at https://pubs.er.usgs.gov/ publication/b1122B.]

Cannon, W.F., Green, A.G., Hutchinson, D.R., Lee, M., Milkereit, B., Behrendt, J.C., Halls, H.C., Green, J.C., Dickas, A.B., Morey, G.B., Sutcliffe, R., and Spencer, C., 1989, The North American Midcontinent Rift beneath Lake Superior from Glimpce seismic reflection profiling: Tectonics, v. 8, no. 2, p. 305-332. [Also available at https://doi.org/10.1029/TC008i002p00305.]

Chidester, A.H., Albee, A.L., and Cady, W.M., 1978, Petrology, structure, and genesis of the asbestos-bearing ultramafic rocks of the Belvidere Mountain area in Vermont: U.S. Geological Survey Professional Paper 1016, 95 p., 4 pls. (scale 1:12,000), and 1 oversize table in pocket. [Also available at https://pubs.er.usgs.gov/publication/pp1016.]

Chizmeshya, A.V.G., McKelvy, M.J., Squires, K., Carpenter, R.W., and Béarat, H., 2007, A novel approach to mineral carbonation-Enhancing carbonation while avoiding mineral pretreatment process cost: U.S. Department of Energy, prepared by Arizona State University, Tempe, Ariz., 29 p., accessed October 23, 2017, at https://doi.org/10.2172/924162.

Cipolli, F., Gambardella, B., Marini, L., Ottonello, G., and Vetuschi Zuccolini, M., 2004, Geochemistry of high-pH waters from serpentinites of the Gruppo di Voltri (Genova, Italy) and reaction path modeling of $\mathrm{CO}_{2}$ sequestration in serpentinite aquifers: Applied Geochemistry, v. 19, no. 5, p. 787-802. [Also available at https://doi.org/10.1016/ j.apgeochem.2003.10.007.]

Coleman, R.G., 1977, Ophiolites-Ancient oceanic lithosphere?: New York, Springer-Verlag, 229 p.

Coleman, R.G., 1996, New Idria serpentinite-A land management dilemma: Environmental and Engineering Geoscience, v. II, no. 1, p. 9-22. [Also available at https://doi.org/10.2113/gseegeosci.II.1.9.]
Dahowski, R.T., Dooley, J.J., Davidson, C.L., Bachu, S., and Gupta, N., 2005, $\mathrm{A} \mathrm{CO}_{2}$ storage supply curve for North America-Report PNWD-3471 prepared by Batelle, Pacific Northwest Division, in Building the cost curves for $\mathrm{CO}_{2}$ storage - North America: International Energy Agency Greenhouse Gas R\&D Programme Report 2005/3, variously paged. [Also available at http://ieaghg.org/docs/ General_Docs/Reports/2005_03.pdf.]

Daval, D., Hellmann, R., Martinez, I., Gangloff, S., and Guyot, F., 2013, Lizardite serpentine dissolution kinetics as a function of $\mathrm{pH}$ and temperature, including effects of elevated $p \mathrm{CO}_{2}$ : Chemical Geology, v. 351, p. 245-256. [Also available at https://doi.org/10.1016/j.chemgeo. 2013.05.020.]

Daval, D., Sissmann, O., Menguy, N., Saldi, G.D., Guyot, F., Martinez, I., Corvisier, J., Garcia, B., Machouk, I., Knauss, K.G., and Hellmann, R., 2011, Influence of amorphous silica layer formation on the dissolution rate of olivine at $90{ }^{\circ} \mathrm{C}$ and elevated $p \mathrm{CO}_{2}$ : Chemical Geology, v. 284, nos. 1-2, p. 193-209. [Also available at https:// doi.org/10.1016/j.chemgeo.2011.02.021.]

Ellsworth, W.L., 2013, Injection-induced earthquakes: Science, v. 341, no. 6142, p. 1225942-1 to 1225942-7. [Also available at https://doi.org/10.1126/science.1225942.]

Environmental Systems Research Institute, Inc. (ESRI), 2007a, U.S. State boundaries, in ESRI data \& maps 2007: Redlands, Calif., ESRI.

Environmental Systems Research Institute, Inc. (ESRI), 2007b, World continents, in ESRI data \& maps 2007: Redlands, Calif., ESRI.

Evans, K.F., Zappone, A., Kraft, T., Deichmann, N., and Moia, F., 2012, A survey of the induced seismic responses to fluid injection in geothermal and $\mathrm{CO}_{2}$ reservoirs in Europe: Geothermics, v. 41, p. 30-54. [Also available at https:// doi.org/10.1016/j.geothermics.2011.08.002.]

Falk, E.S., and Kelemen, P.B., 2015, Geochemistry and petrology of listvenite in the Samail ophiolite, Sultanate of Oman-Complete carbonation of peridotite during ophiolite emplacement: Geochimica et Cosmochimica Acta, v. 160, p. 70-90. [Also available at https://doi.org/10.1016/ j.gca.2015.03.014.]

Faunt, C.C., 2012, Alluvial boundary of California's Central Valley: U.S. Geological Survey dataset, accessed June 5, 2018, at https://catalog.data.gov/dataset/alluvial-boundaryof-californias-central-valley.

Fram, M.S., and Shelton, J.L., 2015, Groundwater quality in the Cascade Range and Modoc Plateau, California: U.S. Geological Survey Fact Sheet 2014-3123, 4 p., accessed June 5, 2018, at http://pubs.er.usgs.gov/ publication/fs20143123. 
Fuis, G.S., Zucca, J.J., Mooney, W.D., and Milkereit, B., 1987, A geologic interpretation of seismic-refraction results in northeastern California: Geological Society of America Bulletin, v. 98, no. 1, p. 53-65. [Also available at https://doi.org/10.1130/0016-7606(1987)98<53:AGIOSR> 2.0.CO;2.]

Gadikota, G., 2014, Geo-chemo-physical studies of carbon mineralization for natural and engineered carbon storage: New York, Columbia University, Ph.D. dissertation, 220 p. [Also available at https://doi.org/10.7916/D8KH0K9J.]

Gadikota, G., Matter, J., Kelemen, P., and Park, A.-H.A., 2014, Chemical and morphological changes during olivine carbonation for $\mathrm{CO}_{2}$ storage in the presence of $\mathrm{NaCl}$ and $\mathrm{NaHCO}_{3}$ : Physical Chemistry Chemical Physics, v. 16, no. 10, p. 4679-4693. [Also available at https://doi. org/10.1039/c3cp54903h.]

Gadikota, G., Natali, C., Boschi, C., and Park, A.-H.A., 2014, Morphological changes during enhanced carbonation of asbestos containing material and its comparison to magnesium silicate minerals: Journal of Hazardous Materials, v. 264, p. 42-52. [Also available at https://doi.org/10.1016/ j.jhazmat.2013.09.068.]

Gadikota, G., and Park, A.-H.A., 2015, Accelerated carbonation of $\mathrm{Ca}$ - and $\mathrm{Mg}$-bearing minerals and industrial wastes using $\mathrm{CO}_{2}$, chap. 8 of Styring, P., Quadrelli, E.A., and Armstrong, K., eds., Carbon dioxide utilisation-Closing the carbon cycle: Amsterdam, Netherlands, Elsevier, p. 115-137, accessed March 1, 2018, at https://doi.org/ 10.1016/B978-0-444-62746-9.00008-6.

Gadikota, G., Swanson, E.J., Zhao, H., and Park, A.-H.A., 2014, Experimental design and data analysis for accurate estimation of reaction kinetics and conversion for carbon mineralization: Industrial \& Engineering Chemistry Research, v. 53, no. 16, p. 6664-6676. [Also available at https://doi.org/10.1021/ie500393h.]

Gan, W., and Frohlich, C., 2013, Gas injection may have triggered earthquakes in the Cogdell oil field, Texas: Proceedings of the National Academy of Sciences, v. 110, no. 47, p. 18786-18791. [Also available at https://doi.org/ 10.1073/pnas.1311316110.]

Garrity, C.P., and Soller, D.R., 2009, Database of the geologic map of North America-Adapted from the map by J.C. Reed, Jr. and others (2005): U.S. Geological Survey Data Series 424, 10 p. and GIS data, accessed October 1, 2017 , at https://pubs.usgs.gov/ds/424/.

Gay, T.E., and Aune, Q.A., comps., 1958, Geologic map of California-Alturas Sheet: California Division of Mines and Geology, scale 1:250,000, accessed June 4, 2018, at https://ngmdb.usgs.gov/Prodesc/proddesc_282.htm.
Gerdemann, S.J., O’Connor, W.K., Dahlin, D.C., Penner, L.R., and Rush, H., 2007, Ex situ aqueous mineral carbonation: Environmental Science \& Technology, v. 41, no. 7, p. 2587-2593. [Also available at https://doi.org/10.1021/ es0619253.]

Gislason, S.R., and Oelkers, E.H., 2014, Carbon storage in basalt: Science, v. 344, no. 6182, p. 373-374. [Also available at https://doi.org/10.1126/science.1250828.]

Gislason, S.R., Wolff-Boenisch, D., Stefansson, A., Oelkers, E.H., Gunnlaugsson, E., Sigurdardottir, H., Sigfusson, B., Broecker, W.S., Matter, J.M., Stute, M., Axelsson, G., and Fridriksson, T., 2010, Mineral sequestration of carbon dioxide in basalt-A pre-injection overview of the CarbFix project: International Journal of Greenhouse Gas Control, v. 4, no. 3, p. 537-545. [Also available at https://doi.org/ 10.1016/j.ijggc.2009.11.013.]

Goff, F., Guthrie, G., Lipin, B., Fite, M., Chipera, S., Counce, D., Kluk, E., and Ziock, H., 2000, Evaluation of ultramafic deposits in the Eastern United States and Puerto Rico as sources of magnesium for carbon dioxide sequestration: U.S. Department of Energy, Los Alamos National Laboratory, [Technical Report] LA-13694-MS, accessed October 20, 2017, at https://www.osti.gov/scitech/biblio/754045.

Goff, F., and Lackner, K.S., 1998, Carbon dioxide sequestering using ultramafic rocks: Environmental Geoscience, v. 5, no. 3, p. 89-101. [Also available at https:// pubs.geoscienceworld.org/eg/article-lookup/5/3/89.]

Goldberg, D., 2017, Integrated pre-feasibility study for $\mathrm{CO}_{2}$ geological storage in the Cascadia basin, offshore Washington State and British Columbia: U.S. Department of Energy, National Energy Technology Laboratory, Mastering the Subsurface Through Technology Innovation, Partnerships and Collaboration-Carbon Storage and Oil and Natural Gas Technologies Review Meeting, Pittsburgh, Pa., August 1-3, 2017, presentation, 20 slides. [Also available at https:/www.netl.doe.gov/File\%20Library/ Events/2017/carbon-storage-oil-and-natural-gas/wed/ David-Goldberg-_DOE-review.pdf.]

Goldberg, D.S., Kent, D.V., and Olsen, P.E., 2010, Potential on-shore and off-shore reservoirs for $\mathrm{CO}_{2}$ sequestration in Central Atlantic magmatic province basalts: Proceedings of the National Academy of Sciences, v. 107, no. 4, p. 1327-1332. [Also available at https://doi.org/10.1073/ pnas.0913721107.]

Goldberg, D., and Slagle, A.L., 2009, A global assessment of deep-sea basalt sites for carbon sequestration: Energy Procedia, v. 1, no. 1, p. 3675-3682. [Also available at https://doi.org/10.1016/j.egypro.2009.02.165.] 
Gorecki, C.D., Liu, G., Bruanberger, J.R., Klenner, R.C.L., Ayash, S.C., Dotzenrod, N.W., Steadman, E.N., and Harju, J.A., 2014, $\mathrm{CO}_{2}$ storage efficiency in deep saline formations - A comparison of volumetric and dynamic storage resource estimation methods: International Energy Agency Greenhouse Gas R\&D Programme Technical Report 2014/09, prepared by University of North Dakota, Energy \& Environmental Research Center, variously paged, accessed April 18, 2018, at http:/www.ieaghg.org/publications/technical-reports.

Guyot, F., Daval, D., Dupraz, S., Martinez, I., Ménez, B., and Sissmann, O., 2011, $\mathrm{CO}_{2}$ geological storage-The environmental mineralogy perspective: Comptes Rendus Geoscience, v. 343, nos. 2-3, p. 246-259. [Also available at https://doi.org/10.1016/j.crte.2010.12.007.]

Hänchen, M., Prigiobbe, V., Storti, G., Seward, T.M., and Mazzotti, M., 2006, Dissolution kinetics of fosteritic olivine at $90-150{ }^{\circ} \mathrm{C}$ including effects of the presence of $\mathrm{CO}_{2}$ : Geochimica et Cosmochimica Acta, v. 70, no. 17, p. 4403-4416. [Also available at https://doi.org/10.1016/ j.gca.2006.06.1560.]

Hansen, L.D., Dipple, G.M., Gordon, T.M., and Kellett, D.A, 2005, Carbonated serpentinite (listwanite) at Atlin, British Columbia-A geological analogue to carbon dioxide sequestration: Canadian Mineralogist, v. 43, no. 1, p. 225-239. [Also available at https://doi.org/10.2113/ gscanmin.43.1.225.]

Harrison, A.L., Power, I.M., and Dipple, G.M., 2013, Accelerated carbonation of brucite in mine tailings for carbon sequestration: Environmental Science \& Technology, v. 47, no. 1, p. 126-134. [Also available at https://doi.org/10.1021/ es3012854.]

Harto, C.B., and Veil, J.A., 2011, Management of water extracted from carbon sequestration projects: U.S. Department of Energy, Argonne National Laboratory, Environmental Science Division, [Technical Report] ANL/EVS/R-11/1, 38 p. [Also available at https://doi.org/10.2172/1009368.]

Haywood, H., Eyre, J., and Scholes, H., 2001, Carbon dioxide sequestration as stable carbonate minerals - Environmental barriers: Environmental Geology, v. 41, nos. 1-2, p. 11-16. [Also available at https://doi.org/10.1007/s002540100372.]

Huijgen, W.J.J., and Comans, R.N.J., 2005, Mineral $\mathrm{CO}_{2}$ sequestration by steel slag carbonation: Environmental Science \& Technology, v. 39, no. 24, p. 9676-9682. [Also available at https://doi.org/10.1021/es050795f.]
Intergovernmental Panel on Climate Change, 2005, IPCC special report on carbon dioxide capture and storage [Prepared by Working Group III of the IPCC; Metz, B., Davidson, O., de Coninck, H., Loos, M., and Meyer, L., eds.]: New York, Cambridge University Press, 431 p. [Also available at https:/www.ipcc.ch/pdf/special-reports/srccs/ srccs_wholereport.pdf.]

Intergovernmental Panel on Climate Change, 2007, Climate change 2007-Mitigation of climate change-Contribution of Working Group III to the fourth assessment report of the Intergovernmental Panel on Climate Change [Metz, B., Davidson, O.R., Bosch, P.R., Dave, R., and Meyer, L.A., eds.]: New York, Cambridge University Press, 851 p. [Also available at https://www.ipcc.ch/publications_and_data/ publications_ipcc_fourth_assessment_report_wg3_report mitigation_of_climate_change.htm.]

Irwin, W.P., 2003, Correlation of the Klamath Mountains and Sierra Nevada: U.S. Geological Survey Open-File Report 02-490, 2 sheets, scale 1:1,000,000, accessed October 1, 2017, at https://pubs.usgs.gov/of/2002/0490/.

Jahediesfanjani, H., Warwick, P.D., and Anderson, S.T., 2017, 3D pressure-limited approach to model and estimate $\mathrm{CO}_{2}$ injection and storage capacity-Saline Mount Simon Formation: Greenhouse Gases-Science and Technology, v. 7, no. 6, p. 1080-1096. [Also available at https://doi.org/ 10.1002/ghg.1701.]

Jarvis, A., Reuter, H.I., Nelson, Andrew, and Guevara, Edward, 2008, Hole-filled SRTM [Shuttle Radar Topographic Mission] for the globe, version 4: available from the CGIAR [Consultative Group for International Agricultural Research]-Consortium for Spatial Information SRTM 90m Database, accessed April 17, 2018, at http://srtm.csi.cgiar. org.

Kelemen, P.B., and Hirth, G., 2012, Reaction-driven cracking during retrograde metamorphism-Olivine hydration and carbonation: Earth and Planetary Science Letters, v. 345-348, p. 81-89. [Also available at https://doi.org/ 10.1016/j.eps1.2012.06.018.]

Kelemen, P.B., Matter, J., Streit, E.E., Rudge, J.F., Curry, W.B., and Blusztajn, J., 2011, Rates and mechanisms of mineral carbonation in peridotite - Natural processes and recipes for enhanced, in situ $\mathrm{CO}_{2}$ capture and storage: Annual Review of Earth and Planetary Sciences, v. 39, p. 545-576. [Also available at https://doi.org/10.1146/ annurev-earth-092010-152509.] 
Keranen, K.M., Weingarten, M., Abers, G.A., Bekins, B.A., and Ge, S., 2014, Sharp increase in central Oklahoma seismicity since 2008 induced by massive wastewater injection: Science, v. 345, no. 6195, p. 448-451. [Also available at http://doi.org/10.1126/science.1255802.]

Kirchofer, A., Becker, A., Brandt, A., and Wilcox, J., 2013, $\mathrm{CO}_{2}$ mitigation potential of mineral carbonation with industrial alkalinity sources in the United States: Environmental Science \& Technology, v. 47, no. 13, p. 7548-7554. [Also available at https://doi.org/10.1021/es4003982.]

Krevor, S.C., Graves, C.R., Van Gosen, B.S., and McCafferty, A.E., 2009, Mapping the mineral resource base for mineral carbon-dioxide sequestration in the conterminous United States: U.S. Geological Survey Data Series 414, 14 p., 1 pl., scale 1:5,000,000, accessed August 1, 2017, at https:// pubs.er.usgs.gov/publication/ds414.

Krevor, S.C.M., and Lackner, K.S., 2011, Enhancing serpentine dissolution kinetics for mineral carbon dioxide sequestration: International Journal of Greenhouse Gas Control, v. 5, no. 4, p. 1073-1080. [Also available at https://doi.org/10.1016/j.ijggc.2011.01.006.]

Lambert, D.D., Unruh, D.M., and Gilbert, M.C., 1988, $\mathrm{Rb}-\mathrm{Sr}$ and $\mathrm{Sm}-\mathrm{Nd}$ isotopic study of the Glen Mountains layered complex - Initiation of rifting within the southern Oklahoma aulacogen: Geology, v. 16, no. 1, p. 13-17. [Also available at https://doi.org/10.1130/ 0091-7613(1988)016<0013:RSASNI >2.3.CO;2.]

Levitan, D.M., Hammarstrom, J.M., Gunter, M.E., Seal, R.R., II, Chou, I.-M., and Piatak, N.M., 2009, Mineralogy of mine waste at the Vermont Asbestos Group mine, Belvidere Mountain, Vermont: American Mineralogist, v. 94, no. 7, p. 1063-1066. [Also available at https://doi.org/10.2138/ am.2009.3258.]

Lisabeth, H.P., Zhu, W., Kelemen, P.B., and Ilgen, A., 2017, Experimental evidence for chemo-mechanical coupling during carbon mineralization in ultramafic rocks: Earth and Planetary Science Letters, v. 474, p. 355-367. [Also available at https://doi.org/10.1016/j.epsl.2017.06.045.]

Matter, J.M., and Kelemen, P.B., 2009, Permanent storage of carbon dioxide in geological reservoirs by mineral carbonation: Nature Geoscience, v. 2, p. 837-841. [Also available at https://doi.org/10.1038/ngeo683.]

Matter, J.M., Stute, M., Snaebjörnsdottir, S.Ó., Oelkers, E.H., Gislason, S.R., Aradottir, E.S., Sigfusson, B., Gunnarsson, I., Sigurdardottir, H., Gunnlaugsson, E., Axelsson, G., Alfredsson, H.A., Wolff-Boenisch, D., Mesfin, K., Fernandez de la Reguera Taya, D., Hall, J., Dideriksen, K., and Broecker, W.S., 2016, Rapid carbon mineralization for permanent disposal of anthropogenic carbon dioxide emissions: Science, v. 352, no. 6291, p. 1312-1314. [Also available at https://doi.org/10.1126/science.aad8132.]
Matter, J.M., Takahashi, T., and Goldberg, D., 2007, Experimental evaluation of in situ $\mathrm{CO}_{2}$-water-rock reactions during $\mathrm{CO}_{2}$ injection in basaltic rocks-Implications for geological $\mathrm{CO}_{2}$ sequestration: Geochemistry, Geophysics, Geosystems, v. 8, no. 2, 19 p. [Also available at https://doi.org/ 10.1029/2006GC001427.]

McCafferty, A.E., Langer, W.H., and Van Gosen, B.S., 2016, U.S. Geological Survey cooperative research on carbon dioxide sequestration using ultramafic and carbonate rocks, in Smith, K.S., Phillips, J.D., McCafferty, A.E., and Clark, R.N., eds., Developing integrated methods to address complex resource and environmental issues: U.S. Geological Survey Circular 1413, p. 54-56. [Also available at https://doi.org/10.3133/cir1413.]

McGarr, A., Bekins, B., Burkardt, N., Dewey, J., Earle, P., Ellsworth, W., Ge, S., Hickman, S., Holland, A., Majer, E., Rubinstein, J., and Sheehan, A., 2015, Coping with earthquakes induced by fluid injection: Science, v. 347, no. 6224, p. 830-831. [Also available at https://doi.org/10.1126/ science.aaa0494.]

McGrail, B.P., Schaef, H.T., Glezakou, V.-A., Dang, L.X., and Owen, A.T., 2009, Water reactivity in the liquid and supercritical $\mathrm{CO}_{2}$ phase-Has half the story been neglected?: Energy Procedia, v. 1, no. 1, p. 3415-3419. [Also available at https://doi.org/10.1016/j.egypro.2009.02.131.]

McGrail, B.P., Schaef, H.T., Ho, A.M., Chien, Y.-J., Dooley, J.J., and Davidson, C.L., 2006, Potential for carbon dioxide sequestration in flood basalts: Journal of Geophysical Research, v. 111, no. B12, 13 p. [Also available at https:// doi.org/10.1029/2005JB004169.]

McGrail, B.P., Schaef, H.T., Spane, F.A., Cliff, J.B., Qafoku, O., Horner, J.A., Thompson, C.J., Owen, A.T., and Sullivan, C.E., 2017, Field validation of supercritical $\mathrm{CO}_{2}$ reactivity with basalts: Environmental Science \& Technology Letters, v. 4, no. 1, p. 6-10. [Also available at https://doi.org/ 10.1021/acs.estlett.6b00387.]

Moore, J.G., Clague, D.A., Holcomb, R.T., Lipman, P.W., Normark, W.R., and Torresan, M.E., 1989, Prodigious submarine landslides on the Hawaiian Ridge: Journal of Geophysical Research, v. 94, no. B12, p. 17465-17484. [Also available at https://doi.org/10.1029/JB094iB12p17465.]

Morgan, D., and Grant, T., 2014, FE/NETL $\mathrm{CO}_{2}$ saline storage cost model-Model description and baseline results: U.S. Department of Energy, National Energy Technology Laboratory, [report] DOE/NETL-2014/1659, 26 p. [Also available at https://www.netl.doe.gov/energy-analyses/ temp/FY14_FENETLCO2SalineStorageCostModel DescriptionandBaselineResults_071814.pdf.] 
National Energy Technology Laboratory, 2015, Carbon storage atlas - Fifth edition (Atlas V): U.S. Department of Energy, National Energy Technology Laboratory, DOE/ NETL-2015/1709, 113 p., accessed July 10, 2017, at https:// www.netl.doe.gov/research/coal/carbon-storage/atlasv.

Newall, P.S., Clarke, S.J., Haywood, H.M., Scholes, H., Clarke, N.R., King, P.A., and Barley, R.W., 2000, $\mathrm{CO}_{2}$ storage as carbonate minerals: International Energy Agency Greenhouse Gas R\&D Programme Report PH3/17, prepared by CSMA Consultants Ltd., of Redruth, Cornwall, England, $171 \mathrm{p}$. [Also available at http://www.ieaghg.org/docs/ General_Docs/Reports/Ph3_17\%20Storage\%20as\%20 carbonates.pdf.]

O'Connor, W.K., Dahlin, D.C., Rush, G.E., Gerdemann, S.J., and Penner, L.R., 2004, Energy and economic considerations for ex-situ and aqueous mineral carbonation, in Proceedings of the 29th International Technical Conference on Coal Utilization and Fuel Systems, April 18-22, 2004, Clearwater, Fla.: Gaithersburg, Md., Coal Technology Association, p. 71-82.

Oelkers, E.H., Gislason, S.R., and Matter, J., 2008, Mineral carbonation of $\mathrm{CO}_{2}$ : Elements, v. 4, no. 5, p. 333-337. [Also available at https://doi.org/10.2113/gselements.4.5.333.]

Ojakangas, R.W., Morey, G.B., and Green, J.C., 2001, The Mesoproterozoic Midcontinent Rift system, Lake Superior region, USA: Sedimentary Geology, v. 141-142, p. 421-442. [Also available at https://doi.org/10.1016/ S0037-0738(01)00085-9.]

Olajire, A.A., 2013, A review of mineral carbonation technology in sequestration of $\mathrm{CO}_{2}$ : Journal of Petroleum Science Engineering, v. 109, p. 364-392. [Also available at https:// doi.org/10.1016/j.petrol.2013.03.013.]

Page, N.J, 1976, Serpentinization and alteration in an olivine cumulate from the Stillwater Complex, southwestern Montana: Contributions to Mineralogy and Petrology, v. 54, no. 2, p. 127-137. [Also available at https://doi.org/10.1007/ BF00372119.]

Pan, S.-Y., Chiang, A., Chang, E.-E., Lin, Y.-P., Kim, H., and Chiang, P.-C., 2015, An innovative approach to integrated carbon mineralization and waste utilizationA review: Aerosol and Air Quality Research, v. 15, p. 1072-1091. [Also available at https://doi.org/10.4209/ aaqr.2014.10.0240.]

Park, A.-H.A., and Fan, L.-S., 2004, $\mathrm{CO}_{2}$ mineral sequestration-Physically activated dissolution of serpentine and pH swing process: Chemical Engineering Science, v. 59, nos. 22-23, p. 5241-5247. [Also available at https://doi.org/ 10.1016/j.ces.2004.09.008.]
Park, A.-H.A., Jadhav, R., and Fan, L.-S., 2003, $\mathrm{CO}_{2}$ mineral sequestration - Chemically enhanced aqueous carbonation of serpentine: Canadian Journal of Chemical Engineering, v. 81, nos. 3-4, p. 885-890. [Also available at https://doi.org/ 10.1002/cjce.5450810373.]

Power, I.M., McCutcheon, J., Harrison, A.L., Wilson, S.A., Dipple, G.M., Kelly, S., Southam, C., and Southam, G., 2014, Strategizing carbon-neutral mines-A case for pilot projects: Minerals, v. 4, no. 2, p. 399-436. [Also available at https://doi.org/10.3390/min4020399.]

Power, I.M., Wilson, S.A., and Dipple, G.M., 2013, Serpentinite carbonation for $\mathrm{CO}_{2}$ sequestration: Elements, v. 9, no. 2, p. 115-121. [Also available at https://doi.org/10.2113/ gselements.9.2.115.]

Prigiobbe, V., Costa, G., Baciocchi, R., Hänchen, M., and Mazzotti, M., 2009, The effect of $\mathrm{CO}_{2}$ and salinity on olivine dissolution kinetics at $120^{\circ} \mathrm{C}$ : Chemical Engineering Science, v. 64, no. 15, p. 3510-3515. [Also available at https://doi.org/10.1016/j.ces.2009.04.035.]

Pronost, J., Beaudoin, G., Lemieux, J.-M., Hébert, R., Constantin, M., Marcouiller, S., Klein, M., Duchesne, J., Molson, J.W., Larachi, F., and Maldague, X., 2012, $\mathrm{CO}_{2}$-depleted warm air venting from chrysotile milling waste (Thetford Mines, Canada) - Evidence for in-situ carbon capture from the atmosphere: Geology, v. 40, no. 3, p. 275-278. [Also available at https://doi.org/10.1130/ G32583.1.]

Quick, J.E., 1981, Petrology and petrogenesis of the Trinity peridotite, an upper mantle diapir in the eastern Klamath Mountains, northern California: Journal of Geophysical Research, v. 86, no. B12, p. 11837-11863. [Also available at https://doi.org/10.1029/JB086iB12p11837.]

Reed, J.C., Jr., Wheeler, J.O., and Tucholke, B.E., comps., 2005, Geologic map of North America: Boulder, Colo., Geological Society of America, 28 p., 3 sheets, scale $1: 5,00,000$.

Reidel, S.P., Johnson, V.G., and Spane, F.A., 2002, Natural gas storage in basalt aquifers of the Columbia basin, Pacific Northwest USA-A guide to site characterization: U.S. Department of Energy, Pacific Northwest National Laboratory, [report] PNNL-13962, variously paged [277 p.], accessed October 10, 2017, at https://www.osti.gov/ scitech/servlets/purl/15020781.

Renforth, P., Washbourne, C.-L., Taylder, J., and Manning, D.A.C., 2011, Silicate production and availability for mineral carbonation: Environmental Science \& Technology, v. 45, no. 6, p. 2035-2041. [Also available at https://doi.org] $10.1021 / \mathrm{es} 103241 \mathrm{w}$. 
Robinson, G.R., Jr., Van Gosen, B.S., and Foley, N.K., 2006, Ultramafic-hosted talc-magnesite deposits: U.S. Geological Survey Open-File Report 2006-1229, 14 p., accessed October 23, 2017, at https://pubs.er.usgs.gov/publication/ ofr20061229.

Rosenbauer, R.J., Thomas, B., Bischoff, J.L., and Palandri, J., 2012, Carbon sequestration via reaction with basaltic rocks-Geochemical modeling and experimental results: Geochimica et Cosmochimica Acta, v. 89, p. 116-133. [Also available at https://doi.org/10.1016/j.gca.2012.04.042.]

Ross, M., and Nolan, R.P., 2003, History of asbestos discovery and use and asbestos-related disease in context with the occurrence of asbestos within ophiolite complexes, in Dilek, Y., and Newcomb, S., eds., Ophiolite concept and the evolution of geological thought: Geological Society of America Special Paper 373, p. 447-470. [Also available at https://doi.org/10.1130/0-8137-2373-6.447.]

Rubin, E.S., Davison, J.E., and Herzog, H.J., 2015, The cost of $\mathrm{CO}_{2}$ capture and storage: International Journal of Greenhouse Gas Control, v. 40, p. 378-400. [Also available at https://doi.org/10.1016/j.ijggc.2015.05.018.]

Rudge, J.F., Kelemen, P.B., and Spiegelman, M., 2010, A simple model of reaction-induced cracking applied to serpentinization and carbonation of peridotite: Earth and Planetary Science Letters, v. 291, nos. 1-4, p. 215-227. [Also available at https://doi.org/10.1016/ j.epsl.2010.01.016.]

Saldi, G.D., Schott, J., Pokrovsky, O.S., Gautier, Q., and Oelkers, E.H., 2012, An experimental study of magnesite precipitation rates at neutral to alkaline conditions and $100-200^{\circ} \mathrm{C}$ as a function of $\mathrm{pH}$, aqueous solution composition and chemical affinity: Geochimica et Cosmochimica Acta, v. 83, p. 93-109. [Also available at https://doi.org/ 10.1016/j.gca.2011.12.005.]

Schaef, H.T., McGrail, B.P., and Owen, A.T., 2009, Basalt$\mathrm{CO}_{2}-\mathrm{H}_{2} \mathrm{O}$ interactions and variability in carbonate mineralization rates: Energy Procedia, v. 1, no. 1, p. 4899-4906. [Also available at https://doi.org/10.1016/

j.egypro.2009.02.320.]

Schaef, H.T., McGrail, B.P., and Owen, A.T., 2010, Carbonate mineralization of volcanic province basalts: International Journal of Greenhouse Gas Control, v. 4, no. 2, p. 249-261. [Also available at https://doi.org/10.1016/ j.ijggc.2009.10.009.]

Schaef, H.T., McGrail, B.P., and Owen, A.T., 2011, Basalt reactivity variability with reservoir depth in supercritical $\mathrm{CO}_{2}$ and aqueous phases: Energy Procedia, v. 4, p. $4977-$ 4984. [Also available at https://doi.org/10.1016/ j.egypro.2011.02.468.]
Sen, G., 2014, Introduction to igneous rocks, in Sen, G., Petrology_Principles and practice: New York: Springer, p. 19-49.

Sherrod, D.R., Sinton, J.M., Watkins, S.E., and Brunt, K.M., 2007, Geologic map of the State of Hawai'i: U.S. Geological Survey Open-File Report 2007-1089, 85-p. pamphlet, pls. $1-7$, scale $1: 100,000$, and pl. 8 , scale 1:250,000, and data files, accessed October 1, 2017, at https://pubs.er.usgs. gov/publication/ofr20071089.

Stephens, J.C., and Keith, D.W., 2008, Assessing geochemical carbon management: Climatic Change, v. 90, no. 3, p. 217. [Also available at https://doi.org/10.1007/s10584-0089440-y.]

Tolan, T.L., Reidel, S.P., Beeson, M.H., Anderson, J.L., Fecht, K.R., and Swanson, D.A., 1989, Revisions to the estimates of the areal extent and volume of the Columbia River Basalt Group, in Reidel, S.P., and Hooper, P.R., eds., Volcanism and tectonism in the Columbia River flood-basalt province: Geological Society of America Special Paper 239, p. 1-20. [Also available at https://doi.org/10.1130/SPE239-p1.]

U.S. Army Corps of Engineers, Seattle District, 2016, Fourth five-year review report for Atlas asbestos mine and fifth five-year review for Coalinga asbestos mine, Superfund sites, Fresno \& San Benito Counties, California: Washington, D.C., U.S. Environmental Protection Agency, variously paged [185 p.], accessed October 19, 2017, at https:// yosemite.epa.gov/r9/sfund/r9sfdocw.nsf/3dc283e6c5d605 6f88257426007417a2/1f841c33818b8a8a8825804f005d96 66/\$FILE/Atlas\%204th\%20Coalinga\%205th\%205YR\%20 20160921.pdf.

U.S. Environmental Protection Agency, 2008, Clear Creek Management Area asbestos exposure and human health risk assessment: Washington, D.C., U.S. Environmental Protection Agency, variously paged [160 p.], accessed October 19, 2017, at http://ohv.parks.ca.gov/pages/1140/files/ccma_epaasbestos-exposure-risk-assessment.pdf.

U.S. Geological Survey Geologic Carbon Dioxide Storage Resources Assessment Team, 2013, National assessment of geologic carbon dioxide storage resources-Results (ver. 1.1, September 2013): U.S. Geological Survey Circular 1386, 41 p., accessed March 1, 2018, at https://pubs.usgs. gov/circ/1386/. [Supersedes ver. 1.0 released June 26, 2013.]

Van Baalen, M.R., Francis, C.A., and Mossman, B.T., 1999, Mineralogy, petrology and health issues at the ultramafic complex, Belvidere Mt., Vermont, USA, in New England Intercollegiate Geological Conference, 91st annual meeting, Burlington, Vermont, October 1-3, 1999, Guidebook to field trips in Vermont and adjacent regions of New Hampshire and New York: Burlington, Vt., University of Vermont, Department of Geology, p. 95-111. [Edited by S.F. Wright.] [Also available at https://anrweb.vt.gov/PubDocs/DEC/ GEO/MiscPubs/NEIGC/NEIGC_AnnMtg_1999.pdf.] 
Van Gosen, B.S., 2006a, Reported historic asbestos mines, historic asbestos prospects, and natural asbestos occurrences in the Eastern United States (ver. 2.0, March 2006): U.S. Geological Survey Open-File Report 2005-1189, 1 pl. and data files. [Also available at https://pubs.usgs.gov/ of/2005/1189/.]

Van Gosen, B.S., 2006b, Reported historic asbestos prospects and natural asbestos occurrences in the Central United States (ver. 2.0, March 2006): U.S. Geological Survey Open-File Report 2006-1211, 1 pl. and data files. [Also available at https://pubs.usgs.gov/of/2006/1211/.]

Van Gosen, B.S., 2007a, Reported historic asbestos mines, historic asbestos prospects, and natural asbestos occurrences in the Rocky Mountain States of the United States (Colorado, Idaho, Montana, New Mexico, and Wyoming): U.S. Geological Survey Open-File Report 2007-1182, 1 pl. and data files. [Also available at https://pubs.usgs.gov/ of/2007/1182/.]

Van Gosen, B.S., 2007b, The geology of asbestos in the United States and its practical applications: Environmental and Engineering Geoscience, v. 13, no. 1, p. 55-68. [Also available at https://doi.org/10.2113/gseegeosci.13.1.55.]

Van Gosen, B.S., 2008, Reported historic asbestos mines, historic asbestos prospects, and natural asbestos occurrences in the Southwestern United States (Arizona, Nevada, and Utah): U.S. Geological Survey Open-File Report 2008-1095, 1 pl. and data files. [Also available at https:// pubs.usgs.gov/of/2008/1095/.]

Van Gosen, B.S., 2010, Reported historic asbestos mines, historic asbestos prospects, and other natural occurrences of asbestos in Oregon and Washington: U.S. Geological Survey Open-File Report 2010-1041, 1 pl. and data files. [Also available at https://pubs.usgs.gov/of/2010/1041/.]

Van Gosen, B.S., and Clinkenbeard, J.P., 2011, Reported historic asbestos mines, historic asbestos prospects, and other natural occurrences of asbestos in California: U.S. Geological Survey Open-File Report 2011-1188, 22 p., 1 pl. [Also available at https://pubs.usgs.gov/of/2011/1188/.]

Wells, R.K., Xiong, W., Giammar, D., and Skemer, P., 2017, Dissolution and surface roughening of Columbia River flood basalt at geologic carbon sequestration conditions: Chemical Geology, v. 467, p. 100-109. [Also available at https://doi.org/10.1016/j.chemgeo.2017.07.028.]
White, J.A., and Foxall, W., 2016, Assessing induced seismicity risk at $\mathrm{CO}_{2}$ storage projects-Recent progress and remaining challenges: International Journal of Greenhouse Gas Control, v. 49, p. 413-424. [Also available at https:// doi.org/10.1016/j.ijggc.2016.03.021.]

Wilson, S.A., Dipple, G.M., Power, I.M., Thom, J.M., Anderson, R.G., Raudsepp, M., Gabites, J.E., and Southam, G., 2009, Carbon dioxide fixation within mine wastes of ultramafic-hosted ore deposits-Examples from the Clinton Creek and Cassiar chrysotile deposits, Canada: Economic Geology, v. 104, no. 1, p. 95-112. [Also available at https:// doi.org/10.2113/gsecongeo.104.1.95.]

Wilson, S.A., Raudsepp, M., and Dipple, G.M., 2009, Quantifying carbon fixation in trace minerals from processed kimberlite - A comparative study of quantitative methods using X-ray powder diffraction data with applications to the Diavik Diamond Mine, Northwest Territories, Canada: Applied Geochemistry, v. 24, no. 12, p. 2312-2331. [Also available at https://doi.org/10.1016/ j.apgeochem.2009.09.018.]

Wise, W.S., and Moller, W.P., 1995, Geology and mineralogy of the New Idria district: Rocks \& Minerals, v. 70, no. 1, p. 30-35. [Also available at https://doi.org/10.1080/ 00357529.1995.9926595.]

Zalzal, K.S., 2017, Burying the sky-Turning carbon dioxide into rock: Earth Magazine, v. 62, no. 7, p. 32-41. [Also available at https://www.earthmagazine.org/article/ burying-sky-turning-carbon-dioxide-rock.]

Zhu, W., Fusseis, F., Lisabeth, H., Xing, T., Xiao, X., De Andrade, Z., and Karato, S.-I., 2016, Experimental evidence of reaction-induced fracturing during olivine carbonation: Geophysical Research Letters, v. 43, no. 18, p. 9535-9543. [Also available at https://doi.org/10.1002/2016GL070834.]

Zoback, M.D., and Gorelick, S.M., 2012, Earthquake triggering and large-scale geologic storage of carbon dioxide: Proceedings of the National Academy of Sciences, v. 109, no. 26, p. 10164-10168. [Also available at https://doi.org/ 10.1073/pnas.1202473109.] 



\section{Glossary}

asbestos A fibrous serpentine or amphibole silicate mineral, common in some ultramafic rocks.

aqueous $\mathrm{CO}_{2}$ Carbon dioxide dissolved in water.

basalt A fine-grained, extrusive igneous rock with a silica $\left(\mathrm{SiO}_{2}\right)$ content of 45 to 55 weight percent.

brine Natural high salinity water found in the pore space of sedimentary basin reservoirs

carbonate A class of minerals with the $\mathrm{CO}_{3}{ }^{2-}$ anion.

dunite An ultramafic rock with an olivine content greater than 90 weight percent.

ex situ mineralization Storage processes that occur in rocks removed from their original position.

felsic An adjective used to describe rocks with a $\mathrm{SiO}_{2}$ content greater than 69 weight percent.

hyaloclastites A brecciated and hydrated volcanic rock composed of glass.

in situ mineralization Storage processes that occur in rocks in their original position.

listvenite A completely carbonated ultramafic rock consisting of carbonate and quartz.

mafic An adjective used to describe rocks with a total $\mathrm{MgO}, \mathrm{FeO}, \mathrm{MnO}$, and $\mathrm{Fe}_{2} \mathrm{O}_{3}$ content of 15 to 28 weight percent and $\mathrm{SiO}_{2}$ content of 46 to 54 weight percent.

mineral assemblage A collection of minerals that define a rock.

olivine A magnesium iron silicate mineral with the formula $(\mathrm{Mg}, \mathrm{Fe})_{2} \mathrm{SiO}_{4}$.

ophiolite A portion of the oceanic crust revealed at the surface due to tectonic thrusting.

peridotite An ultramafic, coarse-grained igneous rock with an olivine content greater than 40 weight percent.

quartz A silica oxide mineral with the formula $\mathrm{SiO}_{2}$. retrograde metamorphism A form of rock metamorphism that occurs as pressure and temperature decrease.

serpentine A group of magnesium phyllosilicate minerals with the formula $\mathrm{Mg}_{3} \mathrm{Si}_{2} \mathrm{O}_{5}(\mathrm{OH})_{4}$ including those of the asbestiform variety.

serpentinite A low-temperature metamorphic rock containing serpentine minerals produced from the alteration of ultramafic rocks.

supercritical $\mathbf{C O}_{2}$ Carbon dioxide in a fluid state where it is held at or above its critical temperature and critical pressure, imparting both gas and fluid characteristics.

ultramafic An adjective used to describe rocks with a total $\mathrm{MgO}, \mathrm{FeO}, \mathrm{MnO}$, and $\mathrm{Fe}_{2} \mathrm{O}_{3}$ content of 35 to 46 weight percent and $\mathrm{SiO}_{2}$ content of 42 to 48 weight percent. 

Manuscript was approved on June 15, 2018

For additional information, contact: USGS Energy Resources Program 12201 Sunrise Valley Drive, MS 913 Reston, VA 20192

or visit our website at: https://energy.usgs.gov/

Publishing support provided by the USGS Science Publishing Network Reston Publishing Service Center 
